\title{
VARIACIÓN DIALECTAL Y SOCIOCULTURAL EN LA DOCUMENTACIÓN INDIANA DEL SIGLO XVI
}

\author{
Juan A. Frago Gracia \\ Universidad de Zaragoza
}

1. En el planteamiento de esta cuestión documental dos perspectivas históricas quedan inicialmente implicadas. La primera, la que más evidencias proyecta sobre cualquier investigador, hace referencia a la estratificación social y cultural de la comunidad de hablantes, hecho fácilmente perceptible en la realidad actual del mundo hispánico y que con relieves mucho más marcados hubo de darse en el quinientos, siglo primero y en todos los sentidos fundamental en la colonización lingüistica de la América española. Aludir a ese mayor distanciamiento entre las diferentes capas de la población de la España del xvi no es el resultado de una mera suposición ni una simple propuesta de trabajo para filólogos ajenos a cualquier circunstancia histórica que parezca salirse del campo de su especialidad científica; por el contrario, se trata de algo perfectamente asumido y bastante bien conocido por los historiadores no lingüistas y que nosotros no podemos permitirnos culposamente ignorar del todo; del mismo modo que de nada servirá querer llenar las lagunas en este campo del saber humanístico con un imaginativo diletantismo, ni trasladando al ayer sin más, anacrónicamente, situaciones que son exclusivas del hoy. Ninguna duda nos cabe de que la moderna diversidad social acarrea inevitables consecuencias lingüísticas en lo que a usos normativos toca, y la misma seguridad hemos de tener en el sentido de que semejante condicionamiento separó aún más los límites diastráticos en el español de pasadas centurias. El problema está en adecuar el principio teórico y metodológico, digámoslo así, al análisis textual, de forma que a la premisa del encuadramiento sociológico le siga una consecuente concreción en términos de historia lingüistica.

He dicho que el aspecto sociolingüístico de esta problemática es tal vez el que con mayor unanimidad es aceptado como factor explicativo de numerosos cambios experimentados por el español en su discurrir diacrónico, pero tam- 
bién he sugerido que casi nunca se va más allá de la alusión genérica o de la mera formulación de principios. Como quiera que sea, y en vista de lo que durante toda la Edad Media fue el movimiento expansivo del castellano, parece obvio que con suma dificultad se pueden considerar bajo distintos prismas sus vertientes diastrática y diatópica, y muy cierto es que en no pocos casos resulta una completa torpeza intentarlo siquiera. De la fragmentación territorial del castellano medieval y del español áureo - en definitiva, de lo que don Vicente García de Diego llamó "complejo dialectal" de nuestra lengua - tuvieron clara conciencia autores como el judío de Guadalajara traductor de la Biblia de Alba, Mosé Arragel, y el converso aragonés Gonzalo García de Santa María, así como el castellano Juan de Valdés o el andaluz Bernardo José de Aldrete, componentes de una extensa nómina de eruditos y literatos que, sobre todo en los siglos xvi y xvir, se mostraron atentos a la variación geográfica y social del lenguaje ${ }^{1}$. Aquellos hombres de letras sabían o intuían que su lengua no era enteramente uniforme en todas las regiones del vastísimo dominio en que se hallaba implantada ni en los varios peldaños de la escala sociocultural en los cuales sus usuarios se encontraban repartidos. Pero sucede que actualmente algún que otro hispanista tiene una visión de los hechos quizá más deformada que las que en las referidas menciones librescas se reflejan. Y ello debido al absurdo convencimiento, al cual desde luego ciertas simplificaciones históricas han dado pie, de que a lo largo del Medievo siguió el castellano un proceso inexorable y cuasi mecánico hacia su uniformidad, que se habría visto casi totalmente lograda en el Siglo de Oro, precisamente para que en él pudiera producirse el gran florecimiento literario del español moderno, concepción de la historia que apenas tiene otro asidero que el del voluntarismo providencialista de quienes la profesan.

Las cosas no ocurrieron, sin embargo, de una manera tan lineal en la evolución lingüística, ni la lengua, aunque nos atengamos sólo a su lado normativo, está tan férreamente sujeta a los avatares de la literatura como a veces se pretende. El castellano que se expande por las áreas patrimoniales del leonés y del aragonés acabaría instalándose definitivamente en ellas desplazando a sus romances vernáculos, pero no sin antes verse, en mayor o menor medida, modificado durante el período de contactos y conflictos entre dialectos, hasta configurar las que serían modalidades regionales del español en tales territorios. Este enfoque de la difusión del castellano por áreas lingüísticamente extrañas y de su consiguiente diferenciación diatópica son de general comprensión, pero unanimidad mucho menor hay a la hora de encarar el mo-

1 Numerosas referencias librescas relativas a esta cuestión doy en mi Historia de las bablas andaluzas, Madrid, Arco/Libros, 1993. Y abundantes citas maneja asimismo Fernando González Ollé en «Primeras noticias y valoraciones del andaluz», Boletín de la Real Academia Española, LXVII, 1987, págs. 347-387. 
vimiento expansivo del romance central por los espacios peninsulares que fueron ganados por la acción reconquistadora de Castilla, y es claro que me estoy refiriendo a los resultados lingüísticos de dicha expansión. Porque, por un lado, se estaba tendiendo a la normalización del modo más culto de hablar, que es el que solía reflejarse en los textos escritos, y por otro lado la heterogeneidad demográfica y la mezcla cultural que se dieron cita en las ciudades y en los campos incorporados al ámbito castellano propiciaban tendencias diferenciadoras, que no tardarían en señalar perfiles entre las hablas de Castilla la Vieja y las de Castilla la Nueva, y más pronunciados todavia serian los ribetes de la peculiaridad dialectal establecida en la Novisima Castilla, Andalucía por más señas ${ }^{2}$.

Naturalmente, para abordar con rigor el problema de la difusión del español por los inabarcables horizontes americanos y el de su posterior andadura, lo primero que debe hacerse es plantear cuál era su verdadero estado en el momento de acometerse la colonización lingüística de las Indias, procurando evitar los tópicos al uso y un excesivo reduccionismo. En efecto, es menester tener las ideas claras sobre el hecho de que ni siquiera en la mejor literatura áurea la lengua se halla libre de todas las variantes medievales ni de la pluralidad diatópica: para cerciorarse de ello basta con analizar cuidadosamente corpus de distintos autores, de diversas naturalezas regionales también. Mas igualmente es preciso tener en cuenta que, bajo la primera impresión de uniformidad fonética que la letra de molde da - digo la primera impresión, porque una lectura más atenta de las ediciones príncipes demostrará que esa suposición era engañosa-, a ciencia cierta sabemos que la fractura en el fonetismo castellano-español se había verificado incluso antes de los inicios del Siglo de Oro de nuestras letras. Bien es cierto que tal certeza principalmente nos viene dada por el expurgo de manuscritos andaluces y a través de la comparación de los resultados en esta prospección obtenidos con los que fuentes de otras latitudes peninsulares facilitan. Se trata, pues, de afinar el método filológico y de seleccionar convenientemente los materiales textuales más idóneos para su aplicación, que, en definitiva, serán aquellos que mejor y más directamente plasman lo que fue la lengua hablada de quienes los redactaron. De no ser así, lo mismo que se ha discutido y elucubrado durante más de cien años a favor y en contra del andalucismo del español de América, la querella, con su inconfundible aura de bizantinismo, podría prolongarse durante muchísimo tiempo, incluso indefinidamente, quedando así abonado el terreno para que florezca toda suerte de formulaciones meramente impresionistas, o casi, en materia tan espinosa como es la reconstrucción de los pasos dados por nuestra lengua en el seno de la sociedad indiana, con ella identificada ya por

2 De estas cuestiones trato en $* \mathrm{El}$ castellano hasta su expansión americanaw, Cuadernos Hispanoamericanos, núm. 500, 1992, págs. 41-52. 
varios perfiles lingüisticos. Siendo histórico el problema que enfrentamos, en ninguna parte se ha de buscar su más completa y fidedigna desvelación sino en el análisis documental, algo que se cae de su propio peso, aunque haya quien no lo vea asi $^{3}$.

2. La variación interna del castellano de finales del cuatrocientos se manifiesta tanto en el aspecto morfológico y sintáctico como en el léxico y, por descontado, en el plano fonético también; $y$ no debe perderse de vista el hecho de que con todas aquellas variantes y fluctuaciones hizo el español la travesía del Atlántico. De lejos venían dobletes del tipo e-y, non-no, nin-ni, verná-vendrá, sin dejar de lado los futuros y condicionales tméticos decir lo he y decir lo hia, la doble solución de tenerlo y tenello, o la triple de teniatenie-tenié, con otras más que se atestiguan desde los orígenes del castellano literario, aunque por lo general cada elemento de estas concurrencias lingüísticas estuviera exclusiva o preferentemente adscrito a distintos niveles normativos o a determinados registros de la lengua escrita; y tampoco se había consumado del todo a comienzos del xvi en la entera extensión del mundo hispanohablante la sinonimia de amara y amase, ni la perfecta discriminación de vine y he venido. No obstante, ahora cuenta mucho ya la particularidad geográfica en la difusión de ciertos usos variables, de los cuales unas formas habían logrado extraordinaria implantación en la lengua común mientras sus oponentes se refugiaban dentro de limites territoriales progresivamente más

3 Una visión general del fonetismo andaluz en su vertiente diacrónica que, repito, resulta imprescindible para enfocar correctamente el nacimiento del español americano la proporciono en el libro que cito en la nota 1 , y el entronque del dialecto meridional con la modalidad ultramarina de nuestra lengua lo estudié en $* \mathrm{El}$ andaluz en la formación del espafiol americanow, I Simposio de Filologia Iberoamericana, Zaragoza, Facultad de Filología-Universidad de Sevilla / Libros Pórtico, 1990, págs. 77-96. Por supuesto, en esta cuestión mucho tiene que decir asimismo el conocimiento histórico de las hablas canarias, muy descuidado entre los filólogos españoles y al que Jens Lüdtke ha dedicado varios trabajos, los más recientes de los cuales son «Le Canarien (1402-1404): Ein Beitrag zur Spanischen Sprachgeschichte», Neue Romania, 10, 1991, págs. 21-44; «Kastilisch, Portugiesisch und Leonesisch in einem kanarischen Zauberbuch von 1524/1525», Iberoromania, 33, 1991, págs, 1-15. Este mismo estudioso defiende la necesidad de abordar la historia del español de América en relación no sólo con el peninsular, sino teniendo en cuenta asimismo la trayectoria de otras modalidades de nuestra lengua existentes fuera de Europa: «Geschichte des Spanischen in Ubersee*, Romanistisches Jabrbuch, 41, 1990, págs. 290301. Actitud cientffica bien distinta a la de José Mondéjar, dispuesto a no conceder valor alguno a los lapsus cálami de los documentos meridionales, que tampoco parecen resultarle demasiado familiares, y empeñado en anatematizar a todo aquel que defienda la existencia del dialecto andaluz antes del siglo xIx; un filólogo, pues, con el cual la discusión sobre el andalucismo del español americano se haría eterna. Por otro lado, la necesidad de estudiar el español americano y el español peninsular sin perder de vista una y otra realidad, sobre todo en la etapa fundacional de la primera modalidad, es algo que el más mínimo sentido común impone, como ha puesto de relieve Guillermo L. Guitarte, «Cecear por gracia», Actas del VII Congreso de la ALFAL, Santo Domingo, 1987, t. I, pág. 127. 
reducidos. Es lo que aconteció a la vieja competencia entre tenia, desde mucho antes estandarizada, y tenie (tenié), variante morfofonética que Gonzalo Correas tendría por dialectal de La Mancha y de Andalucía, pero que poco tiempo atrás todavía mantenía alguna presencia en la literatura, pues se testimonia en Santa Teresa y con notable frecuencia recurre a ella Francisco Delicado en La Lozana andaluza ${ }^{4}$. Y hasta entrado el siglo xvir no será raro descubrirla en escritos indianos, incluso en alguno que otro de autor criollo, constituyéndose su comprobación textual en útil referencia para la identificación de la procedencia regional de quien redactó la pieza en cuestión.

Con indudable apresuramiento se ha extendido el acta de defunción de la construcción Art. + Pos. $+\mathrm{N}$ en el español moderno, a pesar de que reiteradamente se emplee, por ejemplo, en la continuación del Lazarillo (Amberes, 1555): la nuestra nao, los mis esforzados, la mi Elvira (dos casos), la mi Luna, la mi compañera, al mi mal logrado ${ }^{5}$. En fuentes americanas, sobre todo en las de carácter jurídico y notarial, a lo largo del xvi se encuentran no pocos testimonios del sintagma arcaico, que no debia ser una simple fijación formularia restringida a los hábitos escriturarios de los curiales, pues asi no se explicaria su pervivencia en hablas centroamericanas y del interior argentino. Similarmente, al tipo oracional de dos palabras con sentido negativo antepuestas al verbo, recuérdese el cidiano "que nadi nol diessen posada" (v. 25), no se le suele conceder más vida que la medieval $y$, sin embargo, aún se rastrea en escritor novohispano del último tercio del quinientos, que a todos los efectos puede pasar por individuo criollo. En efecto, fray Diego Durán decididamente se inclina a favor del uso morfosintáctico moderno, en frases como "si veían que se pasaban los ocho dias que no sacrificaban ninguno ...", "es de saber que ninguno mataban ni sacrificaban que no fuese ofrecido por la gente rica y de algún valor", "a los tales pecadores ocultos no podía nadie entender

- Entre las «formas anticuadas o en trance de arrinconarsen empleadas por Teresa de Jesús cita Rafael Lapesa el imperfecto de indicativo sabién en su Historia de la lengua española, Madrid, Gredos, 1985, 9." edición, pág. 317. Del correspondiente rasgo verbal de Francisco Delicado he tratado en «Norma lingülstica y artificio literario en La Loxana andaluzaw, Philologia Hispalensis, 3, 1986, págs. 50-51.

s Anónimo, edición de Amberes, 1555, y Juan de Luna, edición de París, 1620, Segunda parte del Lazarillo, edición de Pedro M. Pif́ero, Madrid, Ediciones Cátedra, 1988, págs. 134, 147, 229, 235, 236, 241. Se registran igualmente las formas tméticas decirles heis, decille beis, cumplirse ha, hacerse ha (págs. 185, 203, 204), las variantes conjuntivas de que-desque (págs. 135, 139, 154), el empleo de nos por nosotros (págs. 208, 234), así como el muy señalado arcaísmo de hombre indefinido en «cuando hombre, señor, tiene gana de efectuar lo que piensa, acaécele lo que a mí» (pág. 151). En el texto de Juan de Luna, como sabemos de 1620, también hay casos de futuro pleonástico, así responderos ba y contarle be (págs. 310, 339), y testimonios del antiguo mantenimiento de la $-b$ implosiva, en cobdo, cobdicia, cobdiciosos (págs. 282, 291, 297). Muchos más ejemplos como éstos podrían aducirse, probatorios todos ellos de que el español áureo ni siquiera en su vertiente literaria habla sufrido una completa nivelación uniformadora. 
qué especie de pecados hubiesen cometido", lo cual no quita para que al menos en una ocasión, hasta donde mi expurgo de su obra alcanza, el cronista dominico se viera abocado a echar mano de la variante antigua :

Y llegados alli, delante la imagen del ídolo Tláloc mataban aquel niño, dentro en la litera, que nadie no le vela, al son de muchas bocinas y caracoles y flautillas ${ }^{6}$.

Que en el español americano del siglo xvi hubo numerosos hablantes conservadores del rasgo arcaizante es algo que está fuera de toda duda, porque si no dificilmente se entenderia que hasta hoy se mantenga en zonas rurales de Argentina y de Chile, sin que quepa descartar que la encuesta dialectológica pueda añadir nuevos enclaves afectos a este resabio lingüistico. $\mathrm{La}$ innovación y el apego a lo tradicional conviven en proporciones variables en los escritos producidos en Indias durante dicha centuria y, si como muestra vale un botón, traeré a colación unas pocas líneas del granadino Sebastián Vázquez, que las pergeñó en la ciudad de Méjico el año 1558 :

Yo me llamo Sebastián Vázquez [...], y por su real merced fui mucho tiempo reçeptor en su Abdiençia que reside esta çibdad de México. Soy natural de la çibdad de Granada, aunque mis padres no lo fueron de alll, sino del Reyno de Castilla la Vieja $[\ldots]$. Aunque su merced no me conosçe ni creo de mí terná notiçia, así por el mucho tiempo que ha que pasé a estas partes, como por aver yo nasçido y criádome en Granada y su merçed no. Residí en aquella real Abdiençia en el oficio del Secretario Diego Gómez de Gumiel diez años; ha ueynte que pasé a esta Nueba Espafia; ha diez y siete que me casé en esta çibdad con hija de Francisco de Terrazas, uno de los primeros conquistadores de esta Nueua España que a ella pasaron con el Marqués ?

Observamos en este breve pasaje la coexistencia de las formas antiguas cibdad y terná con las definitivamente triunfantes $y, n o, n i$, soy, amén del giro "por aver yo nacido y criádome en Granada", corriente en el español del Siglo de Oro. En el mismo castellano medieval había surgido la variación cibdadcirdad, como se había iniciado la competencia de nos con nosotros, la de vos con vuestra merced, la de quien con quienes para la expresión del plural o la de ge lo con se lo. A mediados del xvi, ya lo he advertido en la nota 5, algunos hablantes todavía mostraban un cierto apego hacia el nos 'nosotros', y

- Fray Diego Durán, Historia de las Indias de Nueva España e islas de la Tierra Fir. me, edición de Ángel Marfa Garibay, México, Editorial Porrúa, 1984, t. I, págs. 83, 130, 141, 157. Estas páginas corresponden al Libro Primero de la obra de Durán, acabado de escribir en 1570 y el autor, aunque nacido en Sevilla, se trasladó a tierras americanas sien. do niño y allf se educó, creció y vivió, hasta el punto de que en sus escritos la mayor familiaridad que muestra es con lo indiano, y no con lo espańol peninsular.

7 Fragmento de un texto autógrafo de Sebastián Vázquez que utilicé en $« E l$ seseo en. tre Andalucía y Américas, Revista de Filología Española, 69, 1989, pág. 302. En el presente estudio va reproducido el final de dicho documento (v. lámina IV). 
lo propio se descubre incluso mucho después en textos andaluces, y el empleo de quienes como plural de quien aún no se ha regularizado totalmente en la actualidad y, si no, piénsese en aquel "nosotros somos quien somos" de Gabriel Celaya. Así, pues, el español pasó a Indias con no pocas fluctuaciones, sumamente antiguas unas y muy recientes otras, y por lo común cuando las variantes estaban amplísimamente difundidas o afectaban a puntos muy sensibles de la lengua, en las dos orillas del Atlántico recibieron idéntico o similar tratamiento. Las conocidas excepciones apenas tendrán la virtud de trazar fronteras regionales dentro del español americano, de manera muy sobresaliente en el caso del voseo y, de cualquier modo, casi todo lo que en morfosintaxis llegaria a adquirir connotación americanista hunde sus raices en la lengua medieval o en la del Siglo de Oro. Ahora bien, las diferencias hoy observables en este terreno lingüístico, tanto las estrictamente privativas de uno u otro dominio como las que sólo lo son de grado, de frecuencia o de contexto pragmático, han ido cuajando muy lentamente, razón por la cual es tarea punto menos que imposible identificar en el siglo xvi un número mínimamente importante de rasgos morfosintácticos capaces de distinguir globalmente al español de España del de América, todavía menos para marcar divisiones en la geografía lingüística indiana. A lo sumo, mediante el análisis morfológico y sintáctico dispondremos de materiales útiles para determinar con mayor concreción la procedencia regional de los españoles que durante dicha centuria en la documentación americana dejaron constancia de su patrimonio idiomático, y con la ayuda de los mismos datos incluso mejoraremos nuestro conocimiento de personales adscripciones socioculturales.

3. Todo menos que precariedad empírica puede hallar el historiador del español de América en el esquilmo del vocabulario contenido en corpus escritos en el Nuevo Mundo. Y en el léxico el particularismo diatópico y diastrático tiene asegurada su presencia, porque ni la cultura popular es exactamente igual en todas las regiones, ni la cultura libresca es la misma en todos los individuos. Ocurre, además, que en español, como en otras muchas lenguas, la diferenciación geográfica se manifiesta mucho más acusadamente en el léxico que en la morfosintaxis, y justamente son las palabras las que, cada una de por sí, reflejan retazos del acervo etnográfico, ideológico y folclórico de los distintos pueblos, y de sus tradiciones mercantiles, artesanas, agrícolas, etc. No es de extrañar, pues, que desde tempranas fechas en Indias aparezcan alusiones, cada vez más frecuentes y variadas, a la diversificación dialectal del léxico español, así ésta de Gonzalo Fernández de Oviedo (año 1535), donde se aprecia el contraste de usos peninsulares bien diferenciados y entre éstos y el que ya se siente como americano: "fesoles..., éstos se hacen acá en Amé- 
rica muy bien ..., llámanse en Aragón judias y en mi tierra arbejas luengas" 8. $\mathrm{Y}$ algo parecido se verifica en las dos siguientes citas de Pedro Cieza de León: "y habían hecho algunas chozas que acá llamamos ranchos, en que estaban para se guarecer del agua", "los españoles, sin perder la virtud de su esfuerzo, hicieron como mejor pudieron ranchos, que llamamos acá a las chozas para guarecerse de las aguas" 9. A mediados del xvi Cieza de León asegura el americanismo de rancho con el valor semántico que el vocablo tiene en estos textos, pero, al mismo tiempo, habiendo nacido el cronista en Llerena, indirectamente nos informa que en Extremadura el término en cuestión era desconocido con dicho significado y corrobora asi su originario arranque andalucista, documentalmente más que sugerido ${ }^{10}$.

Por referencia a la época que nos ocupa, no hay escritor, en España como en América, que con mayor o menor abundancia de rasgos léxicos no revele la identidad de su región natal. Es lo que se comprueba en el leonés fray Bernardino de Sahagún, que mantenía muy vivo el recuerdo de su terruño, pues repetidamente trae a colación las costumbres de Castilla la Vieja —on la cual por entonces, ya se sabe, se solía identificar a los de León- como medio de explicar las de los indios mejicanos, así en este pasaje:

Toda la gente del palacio y la gente de guerra, viejos y mozos, danzaban en otras partes del patio, trabados de las manos y culebreando, a manera de las danzas que los populares hombres y mujeres hacen en Castilla la Vieja ${ }^{11}$.

En ocasiones afina aún más la mención geográfica y entonces es la memoria de su patria chica, la Tierra de Campos, la que fluye por su pluma, como en este párrafo:

Estos capillejos eran a la manera que los capillejos de flores que usan las mozas en Campos, por mayo ${ }^{12}$

o en este otro:

Y traían en las manos unas sonajas con que hacen un son al propósito del cantar; son a la manera de trebejos o trebecinas con que hacen callar a los niños cuando lloran; úsanse en los Campos ${ }^{13}$.

8 Esta cita la maneja J. Corominas en su Diccionario critico etimolbgico castellano e hispánico (con la colaboración de José A. Pascual), Madrid, Gredos, 1980-1991, s. v. frijol.

- Pedro de Cieza de León, Descubrimiento y conquista del Perú, edición de Carmelo Sáenz de Santa Marfa, Madrid, Historia 16, 1986, págs. 50, 80.

${ }_{10}$ Según creo demostrar en «Rancho 'vivienda rural o finca de campo': un andalucismo léxico más del español de Américan, Revista de Filologia Española, 71, 1991, págs. 339-345.

${ }_{11}$ Fray Bernardino de Sahagún, Historia general de las cosas de Nueva España, edición de Ángel Marfa Garibay, México, Editorial Porrúa, 1985, pág. 111.

12 Ibidem.

13 Fray Bernardino de Sahagún, op. cit., pág. 39. 
La última cita trae un trebecina desconocido lo mismo del diccionario académico que del de Corominas, pero cuyo occidentalismo claramente se manifiesta en el sufijo diminutivo -ina, y desde luego no es ésta la única muestra de léxico leonés que en la obra del cronista franciscano puede recogerse. Sin que pretenda la exhaustividad para mi inventario, en los fragmentos que siguen hay un interesante ramillete de voces con difusión exclusiva o preferentemente occidental en el mapa dialectal de la Peninsula Ibérica: "cuando comían o bebian añuzcábanse con la comida y bebida", "las ponían en lugar de ojos unos frijoles negros", "bledos o cenizos", "unos chiflos hechos de barro cocido", "pero los que eran tochos y son alocados reianse de este negocio", "llevaban emplumada la cabeza con plumas blancas a manera de bilma", "sembraban maiz de todas maneras, blanco y amarillo, y colorado y prieto", "yo me he manchado de color prieto", "veis aqui con que habéis de pasar ocho páramos", "en lugar de peinarse escarrapuzábanse los cabellos hacia arriba" ${ }^{14}$.

Se apuntan en las precitadas notas atisbos de un proceso de criollización del léxico hispanoamericano, que en los primeros decenios del siglo xvir se encuentra ya muy consolidado. Verbigracia en el bogotano Rodriguez Freyle, quien con la mayor naturalidad siente suyas palabras como frijol o páramo, que en España habían tenido implantación sólo regional: "con que se comenzó a fertilizar la tierra con estas legumbres $[\ldots]$ y otras raices y frijoles, sin que tuviesen otras semillas de sustento", "desde las cumbres de aquel páramo, la mesma noche los indios con trompetas, fotutos $\mathrm{y}$ otros instrumentos dieron a entender cómo estaban alli" " ${ }^{15}$. En el relato de este autor criollo son varios los americanismos léxicos que han recibido plena carta de naturaleza, por lo cual se emplean con la mayor fluidez, sin acotación textual de ninguna clase, entre ellos estancia, una vez nada más emparejado con el peninsular cortijo, pero precisamente para que quedara constancia de su propiedad americana:

Los labradores, en sus cortijos y heredades o estancias, como aćá decimos, escogen y buscan los mejores pedazos de tierra, y con sus aperos bien aderezados rompen, abren y desentrañan sus venas, hacen sus barbechos ... ${ }^{16}$.

Pocos años antes en Cartagena de Indias el jesuita Alonso de Sandoval, de hecho un criollo más, escribe un tratado doctrinal plagado de americanismos en su vocabulario, de lo cual da buena idea este fragmento suyo:

${ }^{14}$ Fray Bernardino de Sahagún, op. cit., págs. 42, 49, 61, 79, 86, 104, 114, 126, 129 , 135, 206, 207, 210.

16 Juan Rodríguez Freyle, Conquista y descubrimiento del Nuevo Reino de Granada, edición de Jaime Delgado, Madrid, Historia 16, 1986, págs. 110, 229.

16 Juan Rodríguez Freyle, op. cit., pág. 299. De forma aislada, sin definición ni rela. ción sinonímica, aparece estancia en págs. 170, 186, 269, 277. 
Entonces, pues, cuando ya levantan de la obra los negros en las Indias, y de aver todo el día cabado al recestidero del sol y a la inclemencia del agua, descansan si tienen en qué y los importunos y crueles mosquitos les dexan, hasta las tres de la mañana, que buelven a la mesma tarea. Si el negro es estanciero, casi es lo mismo, pues después de aver todo el día macheteado al sol y al agua, expuestos a los mosquitos y távanos y llenos de garrapatas, en un arcabuco, que ni a comer salen dél, tomando un bocado o haziéndoles lo tomen de priessa, están a la noche rallando yuca, cierta raíz, de que hazen cazave, pan que llaman de palo, hasta las diez o más, con un trabajo tan excessivo, que en muchas partes, para que no lo sientan tanto, les están entreteniendo todo aquel tiempo con el son de un tamborzillo, como a gusanos de seda ${ }^{17}$.

Sandoval, igual que Rodriguez Freyle, ha asimilado perfectamente el occidentalismo léxico, pues reiteradamente emplea, entre otros, los términos lama, millo, páramo y prieto ("prietos como la pez") ${ }^{18}$, pero recurre asimismo a voces de origen andaluz, así estero y manijar 'dirigir una hacienda o a un grupo de trabajadores', o el recestidero 'resistidero' que figura en el párrafo últimamente citado ${ }^{19}$. Desde un principio en el español de América los dos componentes dialectales más importantes de su vocabulario son justamente el andaluz y el leonés, y es raro el corpus de una cierta extensión que no se haga eco de ambos. Hemos advertido que fray Bernardino de Sahagún, como leonés que era, tiene en su lengua vocablos propios de la región que lo vio nacer, pero no por ello ignora el uso de un espadarte 'pez espada' ("hocico de espadarte") de antiguo arraigado en el mediodía peninsular ${ }^{20}$. El problema es que en buen número de casos no hay posibilidad de deslindar con precisión lo noroccidental de lo propiamente andaluz, ya que bastantes leonesismos y galleguismos se afincaron en las hablas de Andalucía mucho antes del descubrimiento de América merced a las repoblaciones medievales y, de hecho, el mismo Nebrija testimonia varios occidentalismos de los que han ido desfilando en lo que precede ${ }^{21}$. Pero si ya al emprender el camino de la emi-

17 Alonso de Sandoval, Un tratado sobre la esclavitud, edición de Enriqueta Vila Vilar, Madrid, Alianza Universitaria, 1987, pág. 237. El libro se publicó en Sevilla en 1627 con el título De instauranda aethiopum salute, y el ejemplar de la edición príncipe que se guarda en la Biblioteca Universitaria de la Hispalense ofrece un extraordinario interés para la fonética histórica; lo he expurgado con este fin y reiteradamente lo cito en trabajos actualmente en prensa. El padre Sandoval nació en la capital del Guadalquivir, a los seis años de edad pasó a Indias, donde ya había residido su padre, estudió en Lima y ejerció como jesuita el apostolado entre los negros esclavos cartageneros.

18 Alonso de Sandoval, op. cit., págs. 81, 122, 147, 212, 583.

19 Alonso de Sandoval, op. cit., págs. 64, 160, 610.

20 Fray Bernardino de Sahagún, op. cit., pág. 121. Para la documentación andaluzar de este término, véase J. Corominas, op. cit., s. v. espada.

21 Una primera incursión documental en este problema histórico hice en «Nuevo planteamiento para la historia del occidentalismo léxico en el español de América», Actas de las VII Jornadas de Andalucia y América, Sevilla, Junta de Andalucía, 1990, t. II, págs. 151-167. 
gración a Indias los andaluces llevan usos léxicos de tipificación leonesa o gallego-portuguesa, las cosas se complican sobremanera en su destino americano, porque alli los colonizadores se desparraman en todas las direcciones y se entrecruzan los de unas regiones con los de otras. Es éste un decisivo factor de criollización del léxico hispanoamericano, a saber, que palabras que sólo tuvieron alcance regional en la Península Ibérica se hicieran generales o cobraran una enorme difusión en Indias, circunstancia que se entiende muy bien comparando la suerte que, por ejemplo, han corrido allende y aquende el Atlántico términos como alfajor y maceta, como muchísimos más que en parecida situación llegaron a verse en el Nuevo Mundo. ¿Dónde aprendió fray Diego Durán un frangollar ${ }^{22}$, vocablo andaluz pero de probable ascendencia noroccidental? ¿En su Sevilla natal o por su experiencia vital americana? Poco importa esto a la cuestión que ahora nos atañe, ya que la mezcla de variedades diatópicas y su generalización social serían muy pronto algo corriente, y en buena medida proceso inevitable, en los dominios indianos. Inicialmente, el dialectalismo léxico sirve a la averiguación sobre procedencias regionales en los textos de los emigrados. Luego, el americanismo léxico ayudará a reforzar la identificación de la comunidad colonial con su modalidad lingüística y para que así se sintieran mejor sus diferencias con el español de los peninsulares. Incluso cabría dibujar ciertas isoglosas en la geografía americana con estos materiales léxicos, pero más problemático resultaría trazar caracterizaciones culturales o sociolingüisticas con el auxilio de los regionalismos, desde el punto y hora que también están presentes en la literatura áurea de mayor prestigio, en la de un Mateo Alemán o en la de un Baltasar Gracián, sin ir más lejos ${ }^{23}$.

4. Sin ningún género de duda, es el apartado fonético-fonológico el de mayor rendimiento en la tipificación dialectal y sociocultural del español americano en el siglo xvi. Y ello no por otra razón sino porque en los comienzos de esta centuria en España se había consumado ya el grueso de los fenómenos evolutivos constituyentes del reajuste consonántico del castellano medieval y del fonetismo meridional. De manera, pues, que a Indias pasan usuarios de las dos principales normas fonéticas existentes todavía hoy, con el considerable peso que entre las hablas meridionales tienen, y tenían también entonces, las andaluzas, tanto por cuestiones demográficas y de arraigo social de lo dialectal, como por el específico carácter de algunos de sus rasgos. En América se reúnen gentes de una $\mathrm{y}$ otra modalidad lingüística, dándose inicio así a un

23 Fray Diego Durán, op. cit., t. I, pág. 251: «molían un poco de mafz frangollado y mal molido y revolvíanlo con semilla de bledosw.

2s De los dialectalismos léxicos del jesuita aragonés traté en «El aragonesismo lingüístico en Gracián», Gracián y su época. Actas de la I reunión de filólogos aragoneses, Zaragoza, Institución Fernando el Católico, 1986, págs. 333-363. 
largo proceso de síntesis y de nivelación de los hechos diferenciales, en el cual el triunfo acabaría correspondiéndoles a ciertos modismos profundamente teñidos de andalucismo, y de ellos hay que mencionar al seseo como caso muy especial en todos los sentidos. Y madrugadores son los juicios -0 las impresiones, si se quiere - de quienes advierten esa disparidad normativa en los conquistadores. A mi entender, en el texto inmediatamente aducido planea precisamente la extrañeza que a Bernal Díaz del Castillo, castellano viejo, le causa la dicción del andaluz Jerónimo de Aguilar, en el asombro de su inopinado encuentro:

Luego envió a decir a Cortés con un español que siete indios de Cozumel eran los que alll llegaron en la canoa; y después que hubieron saltado en tierra, en español, mal mascado, y peor pronunciado, dijo: «Dios y Santa María y Sevillaw [...]. Y él dijo, aunque no bien pronunciado, que se decía Jerónimo de Aguilar y que era natural de Ecija, y que tenía órdenes de evangelio; que había ocho años que se había perdido él y otros quince hombres y dos mujeres que iban desde el Darién a la isla de Santo Domingo, cuando hubo unas diferencias y pleitos de un Enciso y Valdivia, y dijo que llevaban diez mil pesos de oro y los procesos de unos contra los otros, y que el navío en que iban dio en Los Alacranes, que no pudo navegar ${ }^{24}$.

Es claro que en apenas ocho años Aguilar no pudo olvidar hasta tal punto el ejercicio de su lengua materna, máxime cuando tan bien recordaba otros detalles de su cautiverio y de los días previos al naufragio, habida cuenta, además, de que era hombre de algunas letras y de que incluso había sabido conservar su viejo libro de horas. $\mathrm{Si}$ el suceso no está seriamente falseado o no nos hallamos ante una exageración literaria y si a Bernal Díaz su prodigiosa memoria no lo traicionó en esta parte de su historia, será bastante obvio que el cronista se estaba refiriendo a la marcada pronunciación dialectal del andaluz. De todos modos, el análisis filológico de la documentación americana arroja información abundantísima y fidedigna como para que por su intermedio sepamos con toda seguridad que el español trasplantado a Indias se encontraba fonéticamente fragmentado. Efectivamente, en lo tocante al fenómeno seseo-ceceoso, los textos escritos por los no andaluces mantienen la distinción de $c-z$ y $s$, mientras mayoritariamente las confunden los de los andaluces, de lo cual aporté pruebas con los 40 manuscritos que empleé en el estudio citado por la nota 7. Bien es verdad que la confusión grafémica no es pareja en todos los autores, sino que depende mucho de la formación intelectual de cada cual, de la disciplina escrituraria adquirida en la escuela o en el oficio curialesco, y hasta de particulares sentimientos de corrección. De toda evidencia es que estas circunstancias no han de echarse en saco roto a la hora de establecer

24 Bernal Diaz del Castillo, Historia verdadera de la conquista de la Nueva España, edición de Miguel León-Portilla, Madrid, Historia 16, 1984, pág. 135. 
la valoración lingüística de los deslices ortográficos cometidos por los distintos escribanos.

El extremo superior de la escala sociolingüistica podríamos personificarlo en el doctor Bartolomé Melgarejo, natural de la localidad sevillana de Alanís, que viajó a Méjico en 1539 y allí fue procurador general de indios, catedrático de Decreto en la recién fundada Universidad y traductor de los clásicos latinos. Pues bien, en cinco cartas suyas, fechadas la primera en 1551 y las dos últimas en 1558, apenas algún aislado caso de padesca y de paresca llega a delatar tímidamente su probable pronunciación seseosa. Pero su meridionalismo fonético tal vez aflore también en un he podido que parece esconder un anteriormente escrito he podio, y con incontestables datos atingentes al relajamiento extremo de /-s/ y de /-r, -1/ se descubre la pronunciación dialectal del culto emigrado. Es asi que Melgarejo en primera instancia escribe sus ánima, por otra cartas, la dichas responsiuas cartas, lo casos, pero, advertido el error, repone la $-s$ elidida sobre la vocal a la que debía seguir, y en el caso de la $-s$ ultracorrecta de en ellos (donde ellos supone un ello neutro) aprovecha su trazo para dibujar la a mayúscula de un inmediato avré (en elloAvré ...), de modo que ni un solo lapsus cálami referente a la /-s/ queda sin enmienda. El espíritu de corrección de este autor llega tan lejos, que en la secuencia contrasus consortes a la ese de doble curva de contras 'contra' le sobreescribe una ese alta, con lo cual aparecerán mejor señaladas las respectivas identidades de contra y de sus. Esa puntillosa minuciosidad formal se manifiesta asimismo en el tratamiento de las grafías representativas de las líquidas implosivas, pues el término dolos 'dolor' ha visto retocada con una $-r$ su anómala $-s$ final, y hutado 'hurtado' lleva una pequeña $r$ colocada entre la $u$ y la $t$, sobre la caja de escritura, de suerte que de la atenta mirada de Melgarejo únicamente escapa un cacográfico necessidar, en el que están implicados los relajamientos de /-r/ y /-d/. Por consiguiente, en la escritura del doctor Melgarejo la escrupulosidad correctora es constante, incluso cuando el pulso le flaquea y su letra pierde esbeltez, lo cual sucede en uno de los textos de 1558, el reproducido en la lámina I, donde se lee el corregido ladichas 'las dichas' y un cibdad recurrente en sus escritos, a los que les da un rancio toque de antigüedad, sin duda reforzado por el ocasional empleo de estó 'estoy'. Aparte del arcaísmo que en determinados aspectos afectaba a las hablas andaluzas del xvi, es incuestionable que el humanista de Alanis era de edad muy avanzada cuando corría el mencionado año 25 .

En el extremo cultural opuesto se sitúan autores de textos como los pu-

26 Los textos de Melgarejo a los que me refiero corresponden a las cartas II-VI citadas en «El seseo entre Andalucía y América», págs. 293-294, y la lámina I pertenece al documento núm. V de los consignados en dicho estudio. En la línea 16 el enmendado la dichas. 
blicados y estudiados por Boyd-Bowman ${ }^{26}$, y en un plano intermedio, aunque quizá más próximo al de los muy incultos, se halla aquel prior de Santo Domingo, fray Diego de Carvajal, totalmente despreocupado por introducir cualquier rectificación en una breve relación de 1577 en la que comete las siguientes cacografías: fiansas, neş̧ecidades, rresçide, zasón; juiendo 'huyendo'; generar 'general'; las casa reales; esterelidad; maruedi 'maravedi' (v. lámina II) ${ }^{27}$. El doctor Melgarejo seguramente mantenía la aspiración procedente del lat. /f-/, puesto que sin excepción pone la $h$ con tal referencia etimológica; pero en Diego de Carvajal esa pronunciación aspirada es indiscutible, porque no sólo emplea con idéntico rigor la misma letra, sino que en juiendo la intercambia con la $j$, lo cual incluso puede indicar una articulación aspirada de la velar $/ \mathrm{x} /$.

A finales de la centuria fundacional del español americano el estado de cosas documental no ha variado sensiblemente. En informe de 15 páginas otorgado en la ciudad de Méjico el año 1591, además de un açé 'hacer' y de las grafías ceceosas cesta 'sexta', cétimas 'séptimas' y supiescen 'supiesen', se registran los errores seseosos de acaesido, administrasión (2 ejs.), audiensias, benibolensia, conçiensia, conosco, conose (6 ejs.), conosimiento, conossió (7 ejs.), desia, desían, desir (10 ejs.), diligensia (2 ejs.), dise (6 ejs.), espesial, espesialmente, exçesión-exesión 'excepción' (4 ejs.), fallesimiento, fallesió (7 ejs.), ynformasión, ynjuisiar 'enjuiciar' (2 ejs.), ynstansias, limpiesa, negosios, nesesidad, notisia (2 ejs.), ofisio, padesen (2 ejs.), paressió, petisión (6 ejs.), pobresa, presensia (3 ejs.), rresensión-rrecençión, satisfasión (4 ejs.), serujsio, sierto, sjté, sinco (3 ejs.), sufisientemente (2 ejs.) ${ }^{28}$. Y, aunque de modo muy esporádico, el marchamo de la corrección no está del todo ausente de este corpus, dado que en la línea $372 \mathrm{del} \mathrm{mismo} \mathrm{la} c$ - de cecretario fue rectificada en $s$. En vista de los porcentajes de faltas que con los datos reseñados

26 Me refiero a las cartas que Peter Boyd-Bowman ofrece en «A Sample of Sixteenth Century 'Caribbean' Spanish Phonology», 1974 Colloquium on Spanish and Portuguese Linguistics, Washington, D. C., Georgetown University Press, 1975, págs. 1-11. Sobre un centenar largo de semejantes textos epistolares del siglo xvI ha realizado su tesis doctoral mi alumno sevillano Francisco Ruiz Fernández.

a7 Transcribí esta carta en «Una introducción filológica a la documentación del Archivo General de Indias», Anuario de Lingüistica Hispánica, 3, 1987, págs. 95-96, y la referencia archivística está en pág. 88 , n. 39. En el vuelto del folio se leen las formas las casa reales, fiansas, esterelidad y nesçecidades.

28 AGI, Sección México, legajo 112: «En la ciudad de México, a veynte y dos días del mes de otubre de mill y quinientos y ochenta y quatro años, estando los señores presidente e oydores de la Audiencia Real .... Sancho López de Agurto, escribano de cámara del rey en la Audiencia de México, autoriza el 21 de mayo de 1591 la copia de la información de oficio hecha en 1584 sobre la petición de ayuda de costa de doña María de Cepeda, viuda del doctor Tomás de la Cámara, alcalde del crimen que habla sido en dicha Audiencia. 
cabe establecer, pocas dudas hay de que el hablar de este amanuense era enteramente seseoso.

Muy poco después, el 20 de enero de 1592 , el alcalde mayor de la provincia de Tabasco envía dos memoriales en denuncia de ciertos desmanes eclesiásticos, destinado el uno al arzobispo de Méjico y el otro al rey, escritos ambos por su secretario ${ }^{29}$. El primer texto, de tres folios en recto y vuelto, trae un repuesta 'respuesta' y un an pagados 'han pagado', tiene plática por práctica, estipendido por estipendio, 6 ejs. de prerlado 'prelado', las grafías ceceosas cauza, pretençión (2 ejs.), prezidençia, prizión, rezide, y las seseosas asertadísima, bengansa, cauesa, sédula, siertos, con notorio equilibrio, por consiguiente, entre las dos últimas clases de faltas. En cambio, el segundo documento, de cuatro folios dobles, que también contiene los elementos cacográficos plática y prerlados junto al doblete estançias de ganado-estançia de ganado, decididamente se decanta por los lapsus cálami ceceosos, cuya predominancia resulta más que evidente si frente a un ynsidençia y un serca se tienen en cuenta las formas auzençia, auizo, çaccrdotes, cauza, marquez, pretençion (2 ejs.), prezo (3 ejs.), proçecución, prouiçión, rezide, rezidençia y rezistençia. Tales proporciones numéricas permiten aventurar la hipótesis de que fuera ceceante el redactor de las dos denuncias, lo que no le quita un ápice al aspecto cultista de su lengua escrita, perceptible lo mismo en el léxico que en cuestiones de morfosintaxis y de estilo, y de manera todavía más concluyente en las enmiendas grafémicas que de su puño y letra hace para remediar deslices iniciales a él mismo debidos, cuando es capaz de notar su presencia sobre el papel, cosa que no siempre ocurre. Otra explicación no cabe al hecho de que en la primera pieza el seseo gráfico de sercania y cavesera se haya rehecho en çercania y cavȩ̧era, dos veces cada caso, y en çerca y ennobleçiese el de serca y ennoblesiese, sin contar con el ar (contracción de preposición y artículo) corregido como $a^{30}$, igual que en la segunda estependido y rrizidenzia alteran sus anómalas $e, i$, respectivamente en $i, \boldsymbol{e}$, idénticamente a como sercanía se convierte en çercanía ${ }^{31}$.

5. Ni que decir tiene, al terminar la decimosexta centuria es posible, y lo será durante todo el período colonial, hallar documentos perfectamente distinguidores de $s$ y $c-z$, documentos cuya autoría generalmente corresponderá

\footnotetext{
20 AGI, Sección México, legajo 112: «El lugar en que el Rey nuestro sefior me puso en esta Provincia de Tauasco .... Carta de Nuño Chaves de Figueroa a don Pedro Moya de Contreras, arzobispo de Méjico, denunciando hechos acaecidos en su jurisdicción; y carta del mismo oficial al rey, denunciando desmanes de eclesiásticos cometidos en su jurisdicción: «En la flota del año passado de nouenta y uno que partió de la Nueua Espafia ....

so Lineas 21, 33, 34, 157, 174, 183, 194.

31 Lineas $19,144,166$.
} 
a sujetos venidos de la España ni ceceante ni seseante. La propia información sobre doña María de Cepeda que acabamos de considerar tiene adjunto un "Parecer" de la Audiencia mejicana escrito con absoluto respeto por la diferenciación ortográfica tradicional ${ }^{32}$. Es muy frecuente que el seseo, o el ceceo, vaya asociado a otros fenómenos de tipo andalucista, pero ya empiezan a abundar, y esto será cada vez más habitual en adelante, los textos en los cuales dicho modismo no va acompañado de más rasgos de carácter meridional. Esta circunstancia apunta a una intensificación del proceso de nivelación dialectal y en algunos casos a la expansión de un sentimiento de identidad criolla que también tendría su vertiente lingüística. Porque en la criollización indiana además del elemento de raza o nación contó mucho el factor cultural ${ }^{33}$, y de hecho no tardan en expresarse las opiniones, no importa que en ocasiones estén basadas en cuestiones meramente anecdóticas, en las que se sugiere que se comenzaba a ver al español de América como una modalidad de la lengua común, así aquella acuñada en Guadalajara el año 1579 que nota: "se llama $[\ldots]$ amole y no amula, porque los españoles tienen corrupto el vocablo" ${ }^{34}$.

Sin embargo, la auténtica piedra de toque en el esclarecimiento de los primeros pasos dados por el español hacia su completa criollización en Indias indefectiblemente habrá de buscarse en la interpretación filológica de los documentos americanos. Un rico filón informativo para ensanchar esta perspectiva histórica se halla en las crónicas y relaciones debidas a personas nacidas en el Nuevo Mundo, de las cuales en Nueva España inaugura la serie Baltasar de Obregón con la obra que, terminada poco antes de 1583, envía un año después al Consejo de Indias. El corpus es heterógrafo, pero en él planea la vigilante mirada del autor, preocupado en introducir correcciones similares a las consignadas más arriba, y si no pocos deslices escapan a su revisión es pre-

\footnotetext{
32 Ocupa el anverso de un folio que acompaña al expediente citado en la nota 28: «A pedimiento de doña María de Cepeda, biuda muger del doctor Thomás de la Cámara, alcalde que fue .... No hace falta advertir que la letra de este texto es de distinta mano que la del corpus confundidor.

3 Francisco Morales Valerio, «Criollización de la Orden franciscana en Nueva España. Siglo xvI», Actas del II Congreso Internacional sobre los franciscanos en el Nuevo Mundo (siglo XVI), Madrid, Editorial Deimos, 1988, pág. 661. Asimismo aporta datos de interés sobre esta problemática Luis C. Mantilla, «La criollización de la Orden franciscana en el Nuevo Reino de Granada» (págs. 685-727). Algunas cuestiones relativas a la criollización lingüística de los frailes españoles trato en «El lenguaje de los escritores franciscanos de América en el S. xvil*, Actas del III Congreso Internacional sobre los franciscanos en el Nuevo Mundo (siglo XVII), Madrid, Editorial Deimos, 1991, págs. 621-637, y en «Visión lingǘrstica de los dominicos del Nuevo Mundo», Los dominicos y el Nuevo Mundo. Actas del III Congreso Internacional, Madrid, Editorial Deimos, 1991, págs. 519-529.

34 Peter Boyd-Bowman, Léxico bispanoamericano del siglo XVI, London, Tamesis Books, 1972, pág. 984, s. v. vocablo.
} 
cisamente porque obedecian a un fonetismo que su habla también tenía plenamente asumido ${ }^{35}$. En el códice de referencia casi todas las manos que lo componen son de hablantes seseosos o ceceosos, asimismo usuarios de más modismos originariamente constitutivos de andalucismo o de meridionalismo, aunque no falta en él un extenso pasaje que muy bien podía haber sido escrito por un castellano norteño. Por entonces iniciaba su extensísimo relato Felipe Guaman Poma de Ayala, indio que aprendió el español con los conquistadores y primeros colonizadores del Perú y, aparte de las interferencias propias de su condición de hablante bilingüe, en el manuscrito que nos ha legado inmediatamente se advierte que el aprendizaje idiomático hispanizador lo llevó a cabo en un medio social donde predominaban los andaluces y otras gentes del occidente peninsular, de manera que escriturariamente se comporta como tantos otros criollos de formación escolar no muy esmerada. En efecto, constantemente se equivoca en el empleo de $s$ y $c-z$ y son frecuentes sus delices tocantes a la $-s$, por elisión o ultracorrección, junto a errores en el uso de $-r$ o en la distinción de $h$ y $x-g-j$, etc., lo que no es óbice para que aquí y allá la pluma de don Felipe deje escapar tímidos destellos de selección cultista, de modo que en la lámina III puede verse un pobrar corregido en poblar al lado de las formas puetas 'poetas', comienso, Zézar e yglecia ${ }^{36}$. Claro que casi todo es lo que queda por hacer en la reconstrucción del ambiente sociolingüístico que la América española vivió en el siglo xvI, pero se trata de un problema en cuyo desentrañamiento debemos empeñarnos si de verdad queremos profundizar en un riguroso conocimiento de cómo nació el español del otro lado del Atlántico y llegó a tomar su propio impulso. Que la cuestión es sumamente compleja, por las ramificaciones sociales y culturales que comporta, y difícil de sustanciar con la debida concreción documental, esto es algo que no puede negarse; pero no por ello vamos a contentarnos con pasar de puntillas sobre ella ni con darla por solventada en apresuradas síntesis, a veces de trasfondo impresionista más que otra cosa. Verbigracia, el hecho de que Martín de Aranguren, natural de Lequeitio (Vizcaya) y emigrado a Indias en 1538, escriba sesárea 'cesárea' en dos cartas que dirige al rey el 7 de agosto de 1551 permite suponer que ese seseo es fruto de su bilingüismo, y el dato nos sitúa en la pista de los refuerzos que el seseo andaluz tuvo en América ${ }^{37}$. Más inquietante aún es el caso del granadino Sebastián Vázquez,

s5 Eva M." Bravo García, Fonética de la crónica criolla de Baltasar de Obregón (Mexico, 1584), Zaragoza, Libros Pórtico, 1990. Esta investigadora ha utilizado para su estudio el manuscrito de dicha crónica conservado en el AGI.

36 Nueva corónica y buen gobierno, edición facsimil, Paris, Institut d'Ethnologie, 1936, pág. 13 (recurro a la reimpresión de 1968). Hay edición crítica de John V. Murra, Rolena Adorno y Jorge L. Urioste (México, 1980), y sin tanto aparato crítico estos estudiosos han publicado el mismo texto cronístico en Madrid, Historia 16, 1987.

37 He aducido la primera carta en $* \mathrm{El}$ seseo entre Andalucla y América», pág. 301; 
hijo de castellanos viejos y con veinte años de permanencia en Nueva España, según propia confesión, quien en 1558 redacta un memorial en el cual consta la grafía disençiones 'disensiones' (v. lámina IV, línea 6) ${ }^{38}$. ¿ Habia adquirido la confusión en Granada o la asimiló en tierras americanas?

Para hablar con fundamento del español de América en el siglo xvi hay que saber antes cuál era la situación del español de España en la misma centuria, pues de otro modo se corre el riesgo de descubrir el Mediterráneo en cambios americanistas que real mente no lo son o que tienen un inmediato precedente peninsular. Pero asimismo es preciso estar familiarizado con la historia del castellano en el cuatrocientos, porque la generación espontánea en la evolución lingüística funciona mucho menos de lo que se cree. En las dos mencionadas cartas de Aranguren se pone pasaxe y dirigida-dirixida, y no se emplea en ellas otra ese que la simple, lo cual, sin embargo, no es privativo de un hablante norteño, pues en un meridional como Sebastián Vázquez también se verifica la indistinción de $s s$ y $s$. Ya he dicho en otra parte que no sirve de mucho buscar la continuidad de la oposición $/ \mathrm{s} / \sim / \mathrm{z} /$ en América, cuando en el español europeo a penas se mantenía en la hora del descubrimiento ${ }^{39}$. Por eso, cuando Rafael Lapesa se refiere a la "fidelidad" a la norma toledana de Diego de Ordaz, como "caso notable, pues Ordaz había nacido en Tierra de Campos" ${ }^{40}$, para mí tengo que lo que de verdad resulta raro en la documentación indiana es hallar piezas perfectamente distinguidoras de $s s$ y $s$, e incluso, aunque en menor grado, de $c$ y $z$, pero no por la procedencia regional de sus autores ni sólo por meras razones culturales. Notablemente culto era Sebastián Vázquez y de Martín de Aranguren sorprende la hermosa caligrafía plasmada en sus textos. Cosa probada es, igualmente, que el panorama fonético para el español americano dibujado por los escritos de mediados del quinientos se atestigua con parecidos rasgos en los primeros cincuenta años del siglo, como en lo que atañe a la confusión seseo-ceceosa se ha demostrado con manuscrito original dominicano de 1517 , en el que también se confirman las alternancias de $s s$ y $s$, predominando en ellas el uso de la grafía

\footnotetext{
la segunda se halla a continuación de la anterior en el mismo legajo y es un duplicado también hecho por Aranguren el mismo día 7 de agosto, con algunas variantes fraseológicas y gráficas. La grafía sesárea se encuentra en los correspondientes sobrescritos.

38 Utilizado en «El seseo entre Andalucía y América», pág. 302: la lámina corresponde al fol. $2 \mathrm{v}$ de la carta. Y véase la nota 7.

30 «El seseo: orfgenes y difusión americana», Historia del español en América, Junta de Castilla y León, Valladolid, 1992, págs. 113-142.

40 Rafael Lapesa, «El estudio del español americano en los últimos decenios: aportaciones y cuestiones pendientes», Actas del III Congreso Internacional de El Español de América, edición de César Hernández y otros, Salamanca, Junta de Castilla y León, 1991, t. I, pág. 11. En honor a la verdad debo confesar que no creo en la existencia de una norma toledana con la enorme influencia lingüística que se le ha atribuido.
} 
sencilla $^{41}$. Y el seseo-ceceo, la pérdida de la /-s/ o la neutralización de /-r, $-1 /$, sin contar con las igualaciones de $s s-s$ y de $c-z$, están presentes en los primerísimos documentos colombinos, que directamente enlazan asi el factor dialectal andaluz con su hijuela americana ${ }^{42}$.

El nudo argumental de esta historia lingüística reside, pues, en la documentación, cuyo manejo exige preparación filológica y una adecuada actitud metodológica. Es necesario, por ejemplo, tomar una postura interpretativa a propósito de las formas que en la escritura adopta el fenómeno seseo-ceceoso, intentando determinar cuándo se trata de un modismo (seseo) y cuándo del otro (ceceo). También hay que decidirse de una vez por todas a prescindir de la información textual que no se base en el análisis de manuscritos $-\mathrm{y}$, en menor medida, de primeras ediciones, sin olvidar las precauciones que su toma en consideración requiere-, estando obligado el estudioso a fijar su criterio sobre la representatividad fonética de las cacografías. Evidentemente, no es igual la corrección que un escribano aragonés hace de eses finales por él mismo puestas indebidamente (v. lámina $\mathrm{V})^{43}$, al fin $\mathrm{y}$ al cabo un lapsus puramente ocasional en su lengua escrita y sin relación de ninguna clase con otros modismos meridionales, que la tachadura aplicada por fray Diego Durán a la $-s$ de "ánimo ynbencibles" ( $v$. lámina VI), porque en el códice de este autor se registran más casos semejantes, junto a elisiones de dicha letra, a cacografías seseo-ceceosas o a signos de la neutralización de /-r, -1/, con otras muestras del andalucismo-americanismo fonético del cronista ${ }^{4}$.

Por ello no es fácil de entender la insistencia de Máximo Torreblanca por sentar cátedra en esta precisa cuestión, siendo que no aporta dato fiable alguno de su propia cosecha y, aún asi, pretende echar por tierra lo que otros sacan a la luz mediante la pesquisa de archivo. Torreblanca presume de la lectura de "millares de documentos" medievales —eso si, impresos-, pero la mayoría de ellos está transcrita y editada por historiadores no lingüistas, en ocasiones con copias hechas sobre copias. Debería tentarse la ropa este estudioso antes de escudarse en su "autoridad" de medievalista para arremeter

41 Jens Lüdtke, «Estudio lingǘstico de la información de los Jerónimos (1517)», Actas del III Congreso Internacional de El Español de América, t. I, págs. 271-279.

- Documentos colombinos de la Casa de Alba, introducción, transcripción y notas de Consuelo Varela, Madrid-Sevilla, Diputación Provincial de Sevilla-Testimonio Compañfa Editorial, 1987, t. I (Estudio y transcripción), t. II (Facsímiles de los documentos).

4 Archivo Municipal de Zaragoza, Libro de pregones del año 1409, fol. 9v, líneas 8-9: *... de la ciudat o de fuera de aquella dentro spacio de vno dias contaderos del día que la present crida .... .

4 Historia de las Yndias de Nueva [España] y Yslas y Tierra Firme de fray Diego Durán, Biblioteca Nacional de Madrid, Ms. Vitrina 26-11, Parte Tercera de 1581, fol. 27v, columna b, línea 37. En la línea 9 de la misma columna hay un ordenansa corregido en ordenança. Aparte de las variantes puramente ortográficas guera-guerra-gerra, esta lámina muestra la indistinción de -ss- y -s-, pues fuera del incorrecto deuissas y del correcto priessa todo es biesen, estubiesen, fuese, asf como la de $\&$ y $z$ en diçe, baçer, baçia, biço. 
contra la obra y el método nada menos que de todo un Menéndez Pidal, y no con la superación de su rigor analítico precisamente ${ }^{45}$. No hay maestro ni doctrina, ni siquiera una mínima aseveración científica, que no deban someterse a la más exigente crítica, siempre dentro del respeto a la verdad y a las personas, y de mi postura al respecto no necesito dar más explicaciones. Pero si se quiere de verdad superar la metodología de la escuela española de lingüistica en la investigación sobre fonética histórica, no quedará más remedio que acudir al manejo de los manuscritos. Todo lo que sea citar por páginas y no por folios, ahí es donde se ve quién utiliza fuentes fiables y quién no, de ninguna manera merece otra cosa que una titubeante aceptación por parte del lector especialista en la materia. Y, por supuesto, las afirmaciones de asiduidad archivística de nada valen si no las corrobora el pie de página de cada estudio. Asi parece que deben ser las cosas en nuestra maltrecha disciplina.

6. Constante es, lo hemos visto, la presencia andaluza en el devenir americano del xvi, hasta llegar a marcar en lo fonético una clara linea divisoria con lo que supone el aporte de otras regiones españolas al común fondo lingüístico indiano, especialmente por relación a las que más alejadas se hallan

45 En relación a una grafía proporcionada por Boyd-Bowman con el acompañamiento del corroborador sic y que yo utilicé a propósito de cierto rasgo fonético americano, dice Torreblanca que la doy como dato «seguro», pero que él ha comprobado «la edición utilizada por Boyd-Bowman» y ve que es una errata de este hispanista; pero ignoro por qué se permite entrecomillar ese adjetivo atribuyéndomelo indebidamente a mí, pues cualquiera que lea el pasaje que me cita comprobará que me limito a remitir dicha forma al autor que la publica: Máximo Torreblanca, «Sobre la pronunciación del español del Caribe en el siglo xvi», Actas del III Congreso internacional de El Español de América, t. I, pág. 358. Lo curioso es que en estas cuestiones haya quien se fabrique dos varas distintas de medir, porque en el mismo artículo este investigador escribe: «Las formas siguientes no son erratas modernas de imprenta. Los editores de varias colecciones diplomática de Castilla indicaron o han indicado explfcitamente, por medio de la partícula sic, que tales formas se encuentran en los manuscritos medievales. Cuando ha sido posible, he comparado ediciones distintas de un mismo documento, o los documentos con los indices de palabras, para comprobar que las formas con letras omitidas, o añadidas, no son errores de imprenta» (pág. 357, n. 12: los subrayados son míos). Argumentos supremos, pero quien los entienda que los compre. Como coda añadiré que alguna que otra edición de las consignadas por Torreblanca no tienen la menor fiabilidad filológica, y otro tanto afirmo de varias transcripciones e impresiones que maneja en $\alpha \mathrm{La}$ representación gráfica y la reproducción de $b$ en el español antiguo», Actas del VII Congreso de la ALFAL, t. I, págs. 437. 445: aviado va quien esta comunicación escribe si piensa que todas sus fuentes corresponden realmente a las fechas que en ellas constan, ¿o es lo mismo una copia que un original? En fin, cuidado con las alegres imputaciones y, otra cosa, no es necesario acudir a la edición expurgada por Boyd-Bowman, pues en su mismo Léxico hispanoamericano del siglo XVI he verificado luego que se puede leer también bácelo (entrada pertiguero), y si antes (s. v. acólito) se pone bácelob la responsabilidad no es mfa: cité como debla y me limité a decir que «sin duda* habría que leer el verbo en plural, hacen, como asf es en efecto. Pero, en fin, dejémonos de «ediciones» y de «sics» y vayamos a la auténtica seguridad de los manuscritos, igual que hacen los cultivadores de otras ciencias históricas que se precian de serlo. 
en el mapa peninsular. No sólo es cuestión de fonética histórica, sin embargo, pues muchísimo influyó asimismo Andalucía occidental en la formación del léxico hispanoamericano, y algo significa en este sentido el caso de rancho. Igual verificación obtendremos si consideramos la voz maceta, que únicamente pudo ser difundida a lo largo y a lo ancho de América por gentes originarias del reino de Sevilla, donde se empleó con nítida distinción semántica frente al vocablo tiesto tal y como se registra en ordenanzas de Lepe del año 1567: "que quando quiera que alguno quisiere sacar los dichos cueros del noque o de los tiestos o logar donde los tuviere..." ${ }^{46}$. En cambio, el rondeño Vicente Espinel testimonia la sinonimia maceta-tiesto, pero también la polisemia del segundo término: “de vn ciprés tan eminente y alto por sembrarlo o plantarlo en vna maceta o tiesto se haze vn arbolillo enano y miserable", "al sabor de vnos carboncillos que tenia encendidos en vn tiesto de cántaro" "47. Y mientras tanto los documentos del norte de España escritos en la misma época ignoran el uso de maceta, en cuyo lugar impera el de tiesto, que, verbigracia, se encuentra en el inventario de bienes muebles y existencias de un especiero zaragozano difunto: "item, cinco tiestos de clabeles" 48 . De sobras sabemos, pues, a quiénes se debe la rápida aclimatación de maceta en el Nuevo Mundo, y continuas sorpresas de este signo iremos recibiendo a poco que profundicemos en el expurgo textual.

En cuanto al aspecto cultural de la documentación indiana, como es lógico responde a los cánones más arraigados en las costumbres escriturarias de España y tanto las enmiendas como los lapsus y las ultracorrecciones unas veces serán de indole estrictamente ortográfica, resultantes de vacilaciones entre normas o tendencias distintas, pero en otras ocasiones tales hechos grafémicos claramente remiten a un conjunto de fenómenos de carácter marcadamente regional, si no dialectal. En el primer orden de cosas, cualquiera que lea los corpus cronísticos de Felipe Guaman Poma de Ayala y de fray Diego Durán inmediatamente verá que el autor indio es mucho más arcaizante en su escritura, continuamente impregnada de resabios medievales, que sin duda han de achacarse al tipo de formación escolar por él recibida. En la segunda perspectiva, la de sentido auténticamente lingüístico, son igualmente similares los comportamientos del escribano a uno y otro lado del Atlántico, así como las implicaciones idiomáticas de sus actos gráficos. Ejemplos de lo que digo se

46 Ordenanzas municipales de Lepe, edición de Antonio González Gómez, Huelva, 1982, pág. 62. Lo mismo se lee en el correspondiente folio del códice lepero.

47 Vicente Espinel, Relaciones de la vida del escudero Marcos de Obregón (Madrid, 1618), edición facsímil de la Real Academia Española y Caja de Ahorros de Ronda, con introducción de Manuel Alvar y José Lara Garrido, Málaga, 1990, fols. 24r, 42r.

18 Angel San Vicente, Instrumentos para una bistoria social y económica del trabajo en Zaragoza en los siglos XV a XVIII, Zaragoza, Real Sociedad Económica Aragonesa de Amigos del Pafs, 1988, t. I, pág. 110. De 1515 es el documento transcrito. 
han señalado en relación a textos indianos adjuntos a estas páginas. De redacciones dadas en la propia Andalucia, y a título simplemente indicativo, aduciré el fragmento de inventario sevillano del año 1582 reproducido por la lámina VII. En él se observa cómo el galicismo chimenea es preferido en su forma primigenia chiminea, si bien la fluctuación está ya presente en el habla del amanuense, que pone una vez chimenea y corrige en $i$ la $e$ del elemento innovador; se verifica asimismo que todavía no habia perdido vigencia la variante toponímica Cáliz 'Cádiz', de tan acusada incidencia en las fuentes antiguas, pues Cádiz se ha cruzado con el nombre común cáliz; y en osteario 'hostiario' está plasmada la hipercorrección que se explica precisamente por el rechazo de las hablas andaluzas al antihiatismo ${ }^{49}$. A detalles como éstos tendrían que atender los que se apresuran a cubrir con la mugrienta capa de la más burda incultura a toda la emigración española, y a la andaluza en particular, que fue a poblar las Indias.

49 AHPS, Oficio $24 .^{\circ}$, libro $3 .^{\circ}$ de 1582 , fol. 90v: *vn cadizliz (línea 8: diz tachado), vn osteario (línea 11), chimenea corregido y chiminea (líneas 23, 24). 


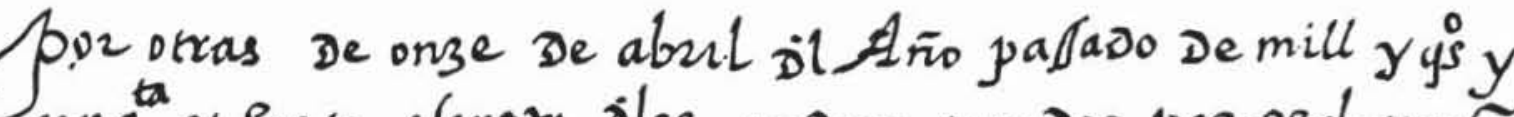
ung y Suete chertibi jlos monos anidos poresclawos $\tilde{g}$ din Reclamado hbertad y sean hbertado Mbersido batacl

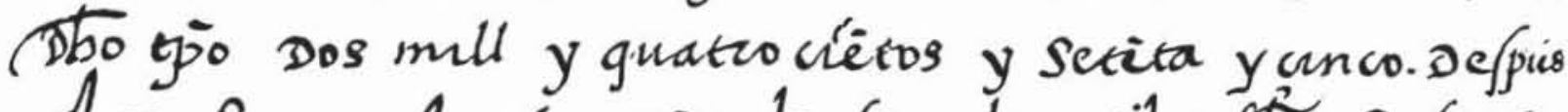

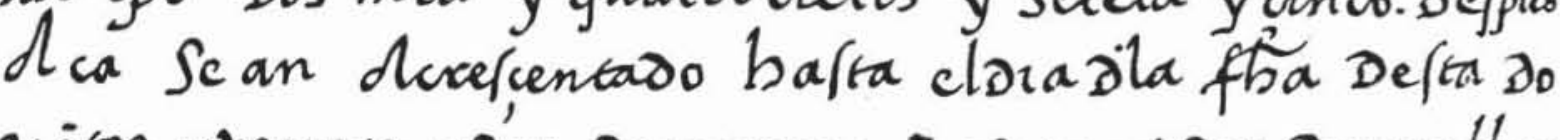

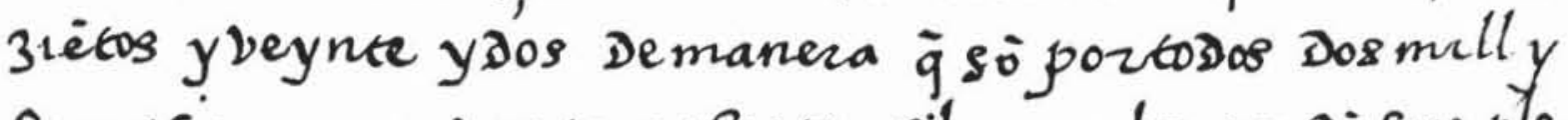
Sey ciétos y mobenta y Suete: ojlos guales pendésius ple

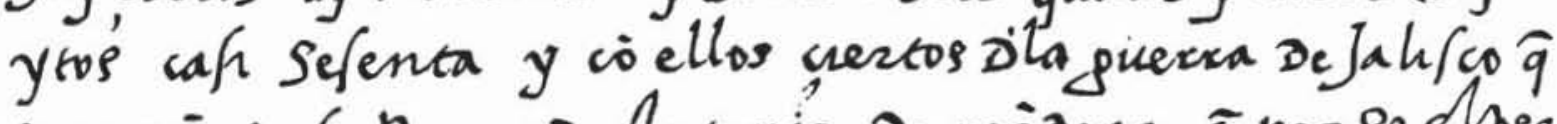
buw vïo bro brey jö Antonio de mèdoca g porsedber Daso porefta su beal audrencía poíesclavos Sepi la grä provanca g cotra ellos Séhr3o tego sin en baxgo otha suphcado efia sus pleytos cöclusospa se de ter

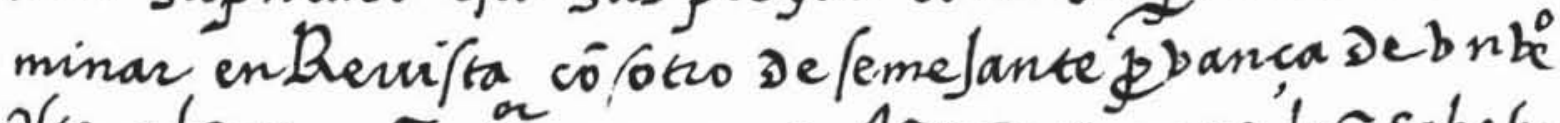

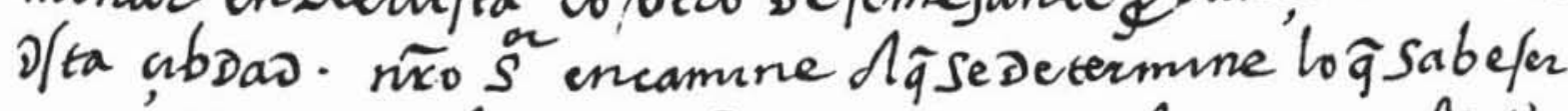

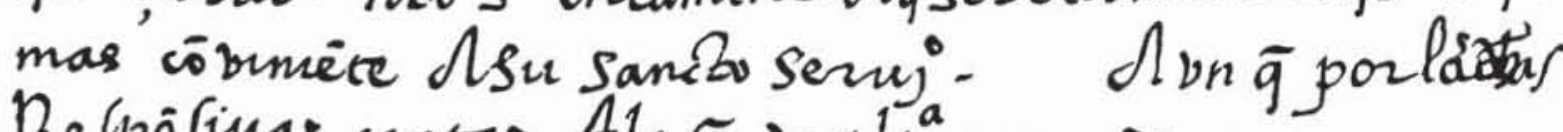

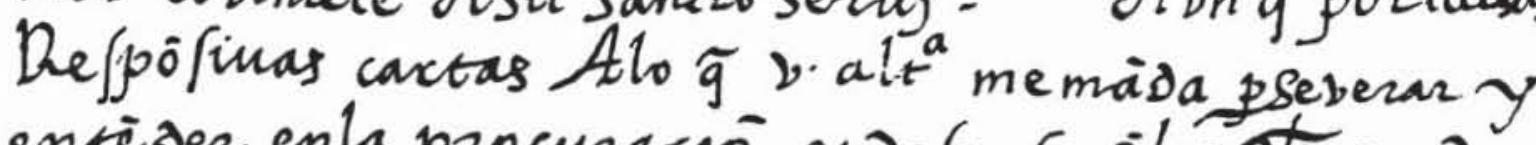
entider enla procuracio y defen a slos othos indios

Lámina I: Corrección de -s por el doctor Melgarejo. 


\section{S. Se, M.}

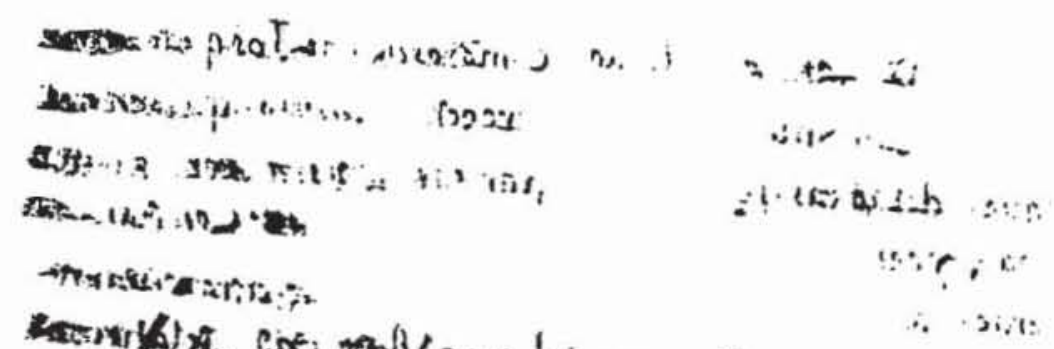

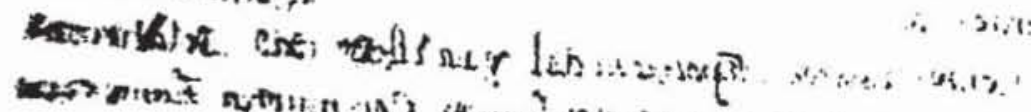

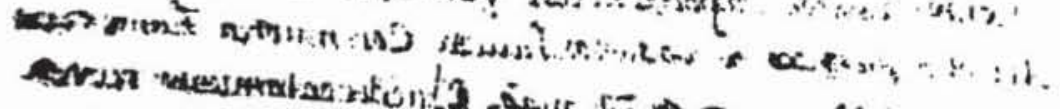

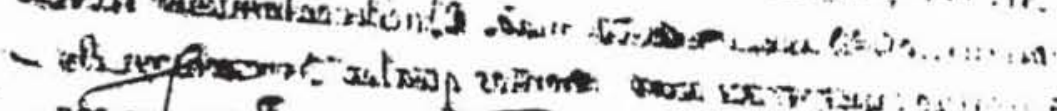

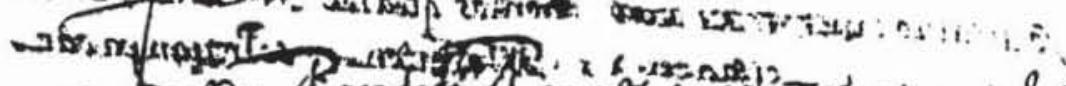

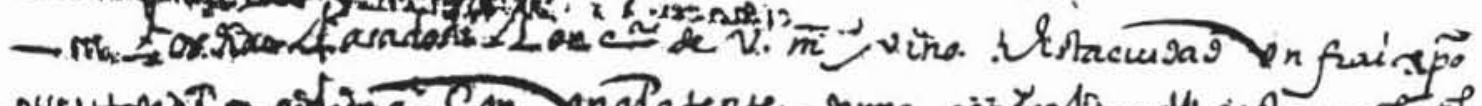

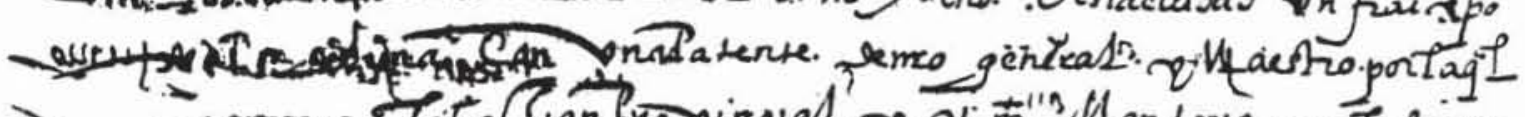

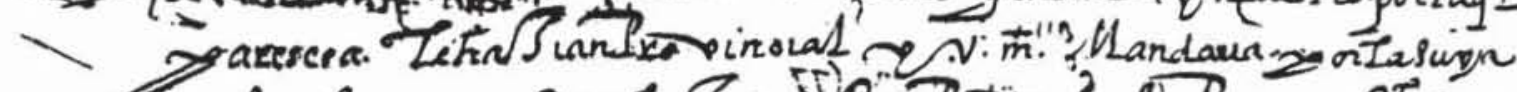

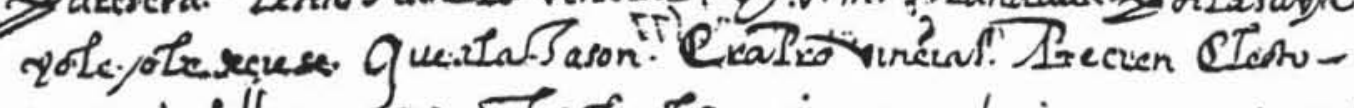

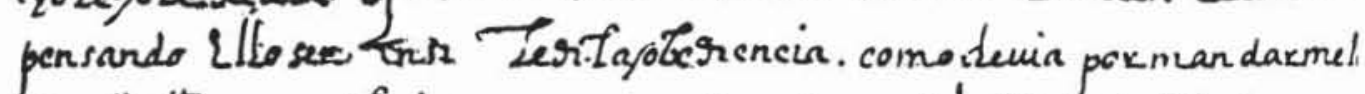

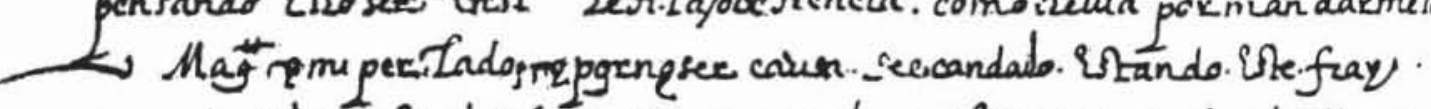

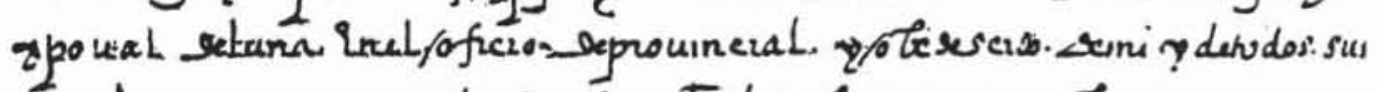

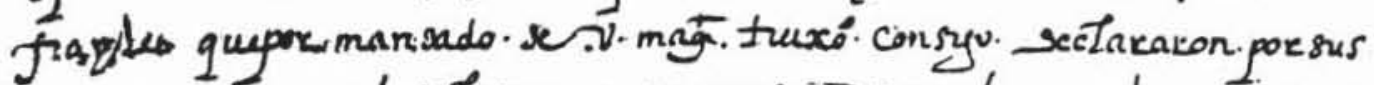
2senes y rumal gobueno quenocracipio vincial. y quela patente. $q$

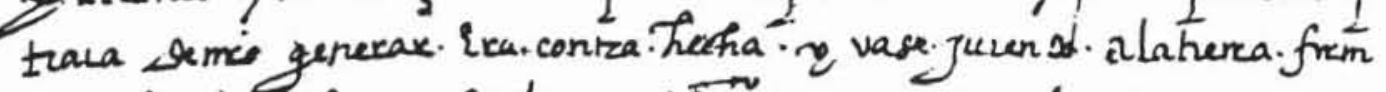

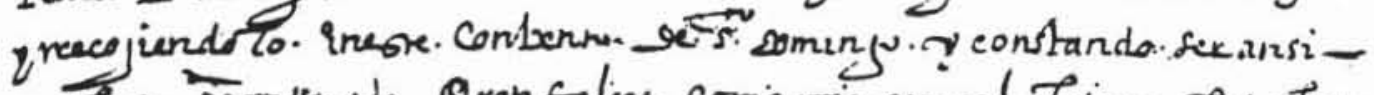

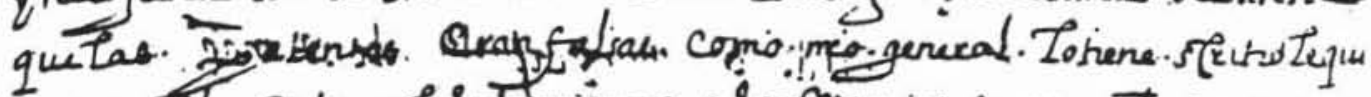

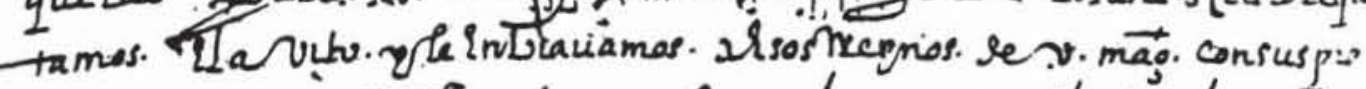

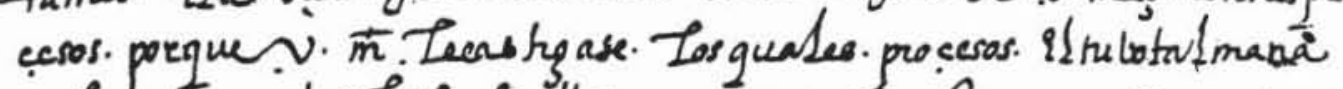
porth max quelos. heito. Inella quo parescento. Somos en furmados. que $v \cdot \frac{1}{m}$. Temando. Sistrer. Suptico. iv. mat. humilementes

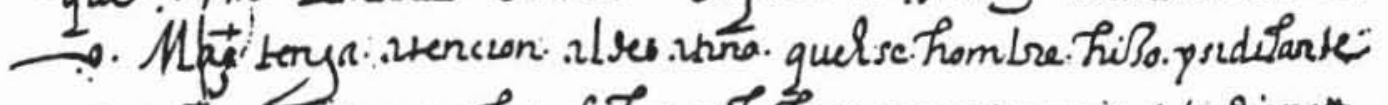

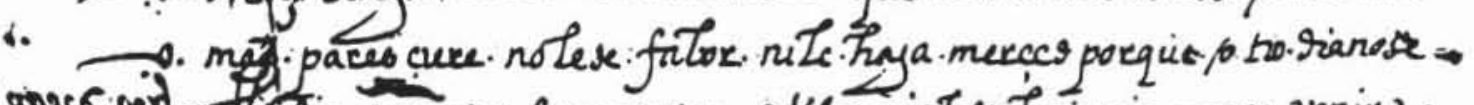

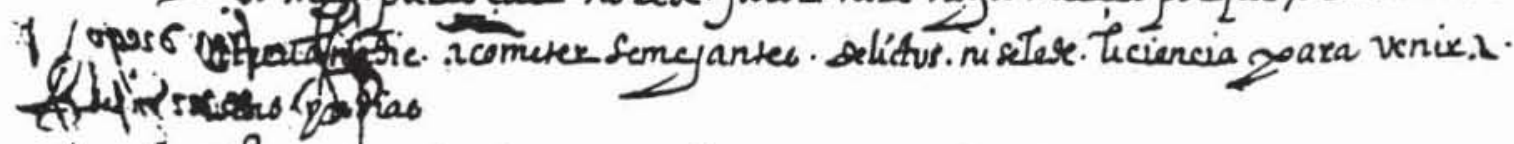

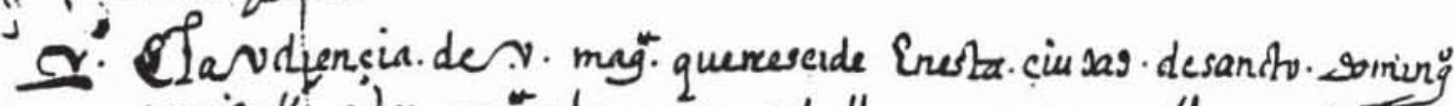

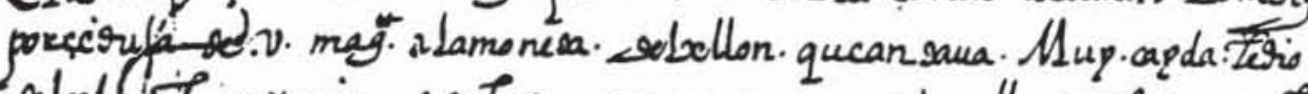

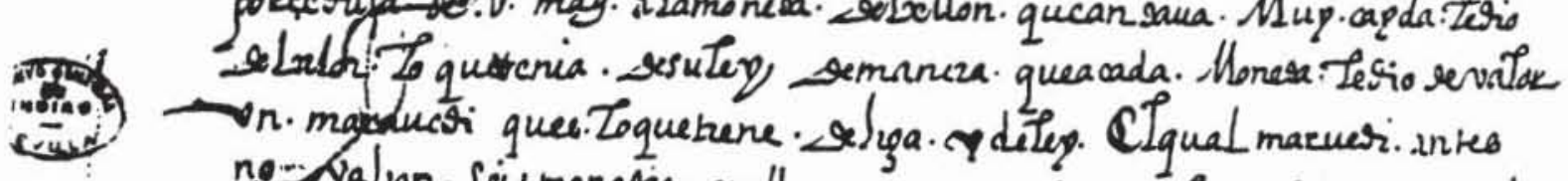
cines

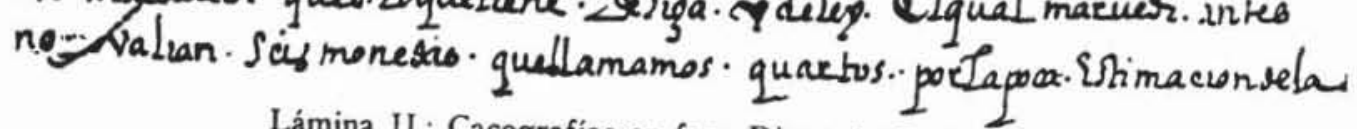
Lámina II : Cacografias en fray Diego de Carvajal. 


\section{"GEVERA CIOU}

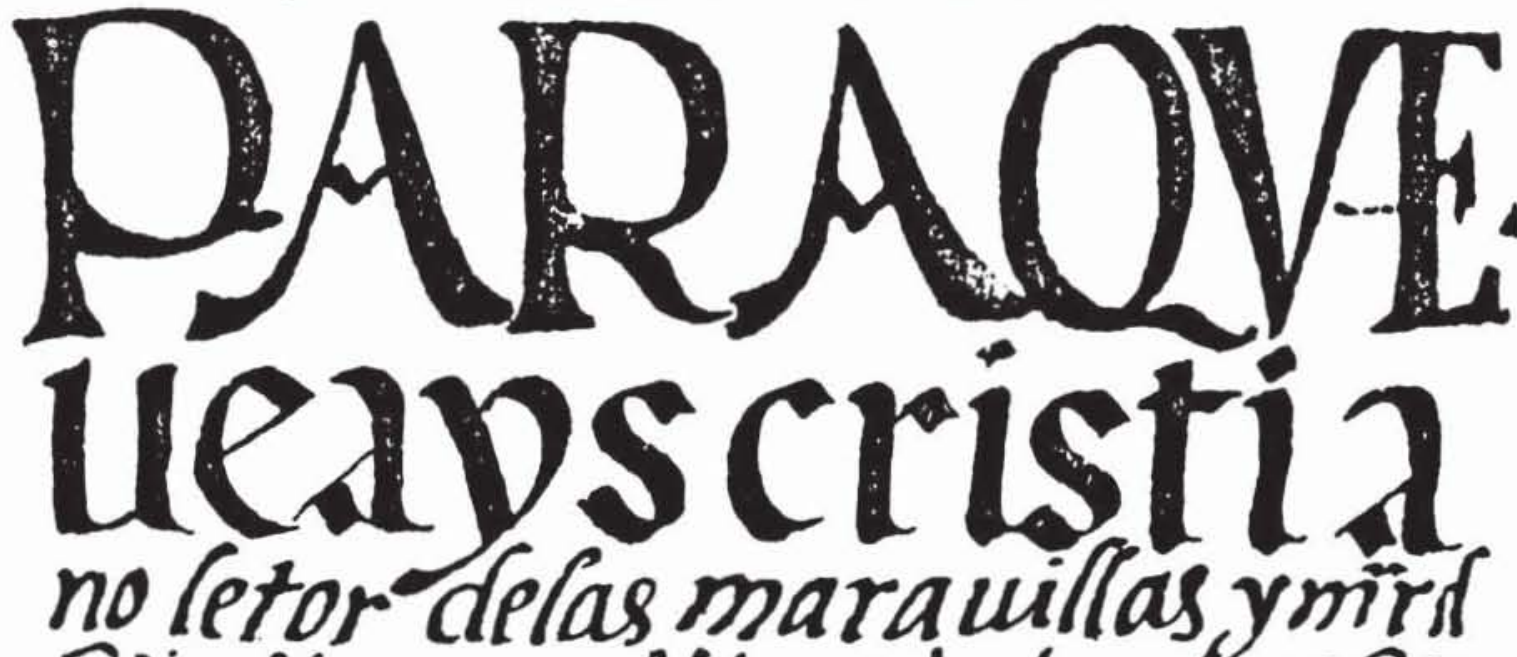
Goios bizo parall Gien rlos bombres 9 co mo dios corio el mundoscys gias y para vee dimir d mun go y los bo m G res trawajo trey tr y tees reños y rin xio y per riolamiay porelmun to $y$ porlos hombres sauienso lomejor relos tienpos y años bizo armes teop aran yanuestra ma gre cua clciclo y la ticera y la agua yuien to pezes yani males to sopara los $50 \mathrm{~m}$ Les yclcielo pa ra poGtar nos alos Gom Gres ypara cllo-

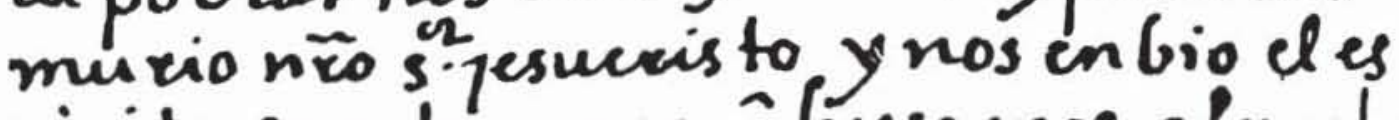
piritu sancto para $\hat{q}$ fuese mos alumbra Los con sugracia seponey seescriue 9 se ra resvela fun racion vel munso rosmi llon y seycientos y roze años res reclio mi enso bas tacl acalo co molo es cei usiccon velos tiexpos y meses y años por los planetas ycursos los ryos puetas y filosofos le tra ras weis to tiles-ypompelio - julio zezar mancos Hanio-y cla mo yloes cricciccon los sanctos apos to bes $y$ ro to res rela staygena $\frac{\text { las }}{4}$

\footnotetext{
Lámina III : Corrección gráfica y seseo-ceceo en Felipe Guaman Poma de Ayala.
} 


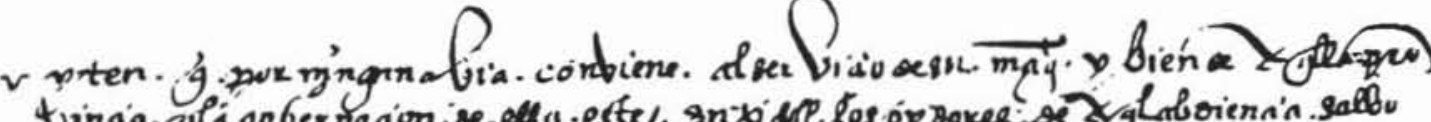

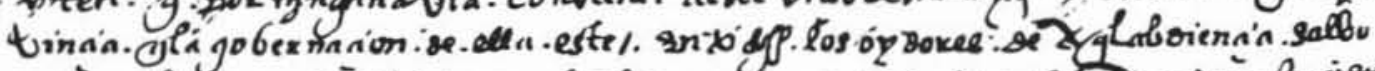

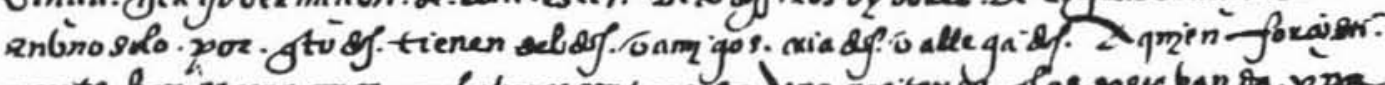

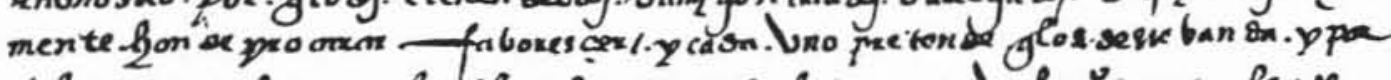

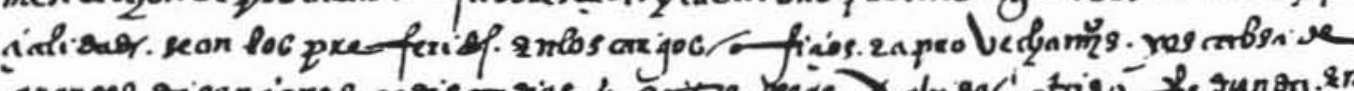

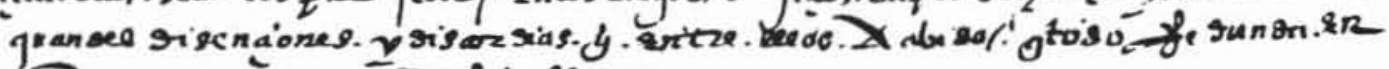

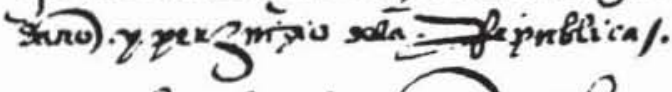

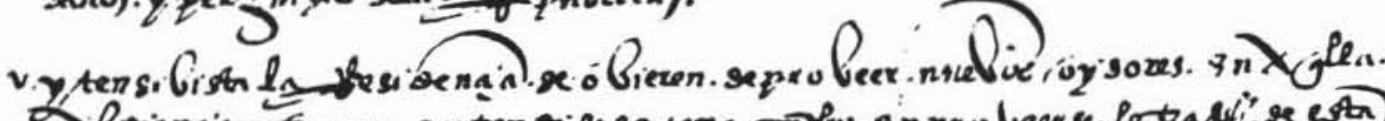

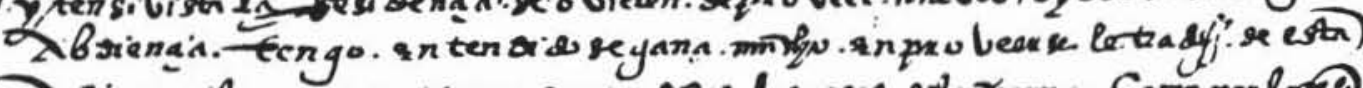

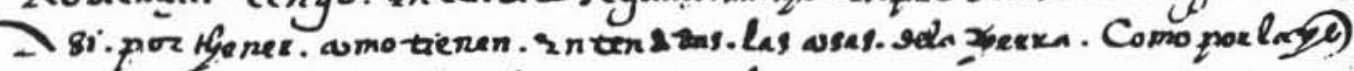

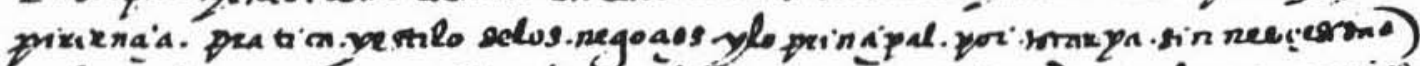

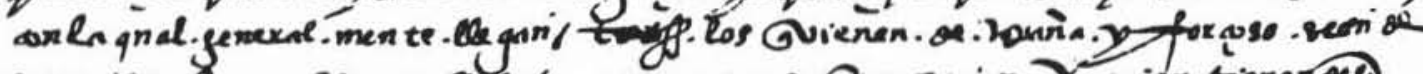

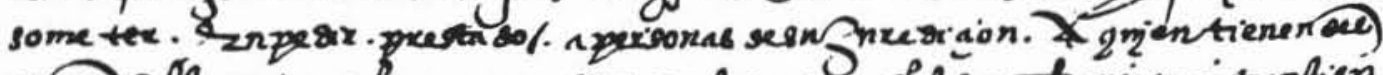

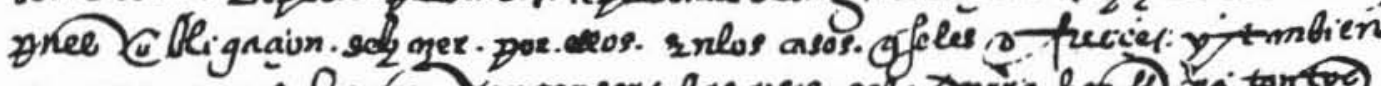

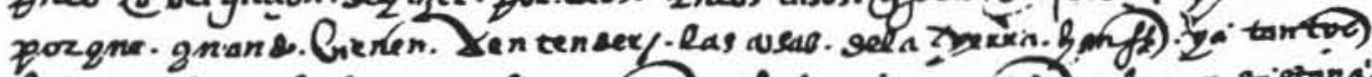

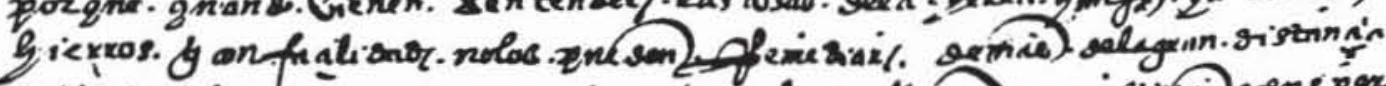

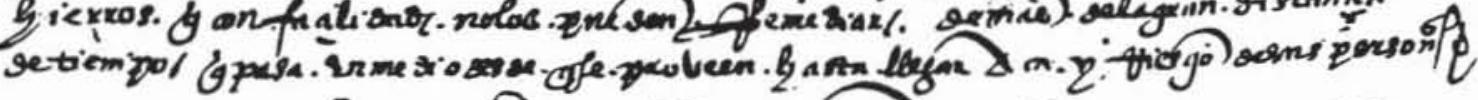

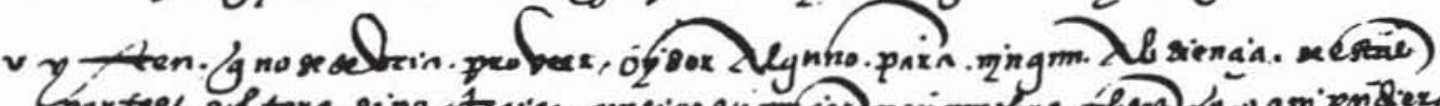

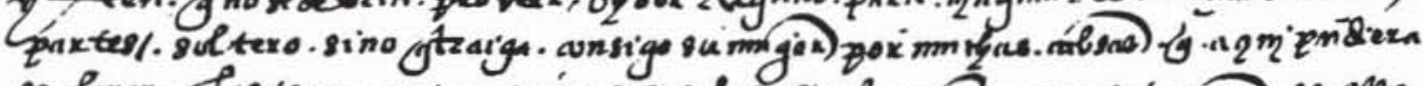

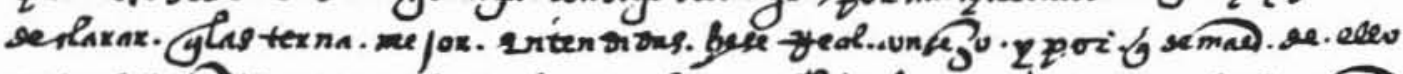

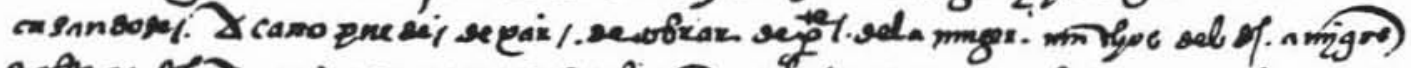

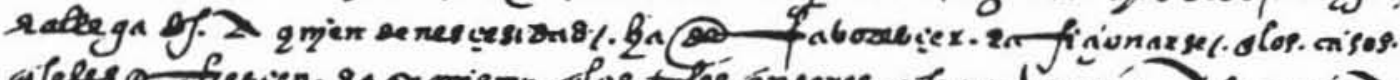

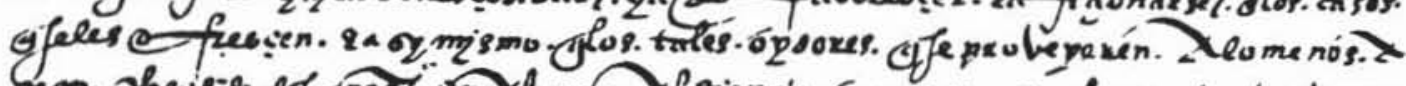

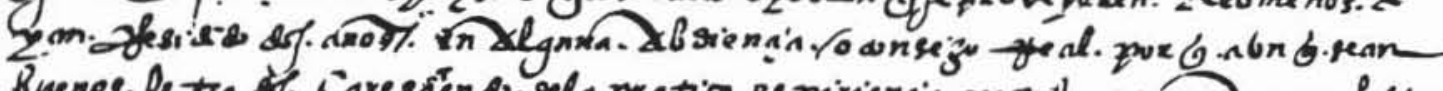

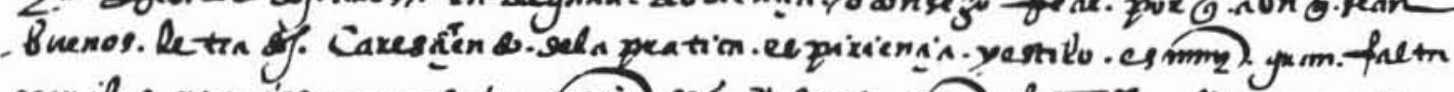

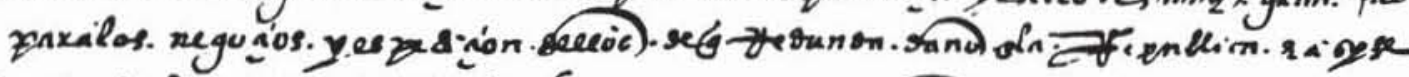
veremens sin.por optpiviensin.

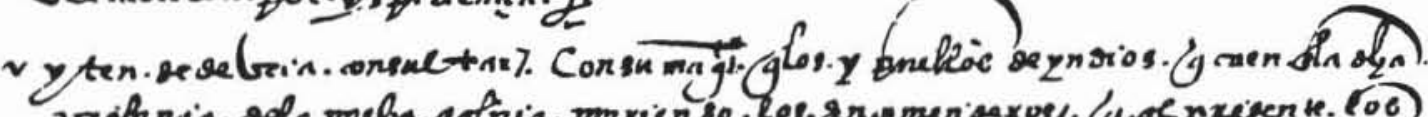

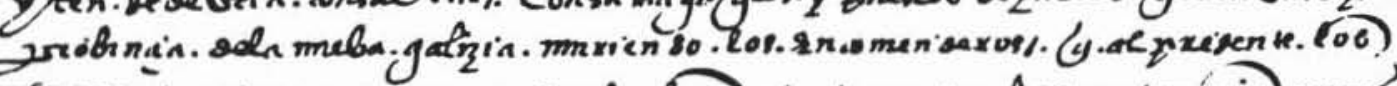

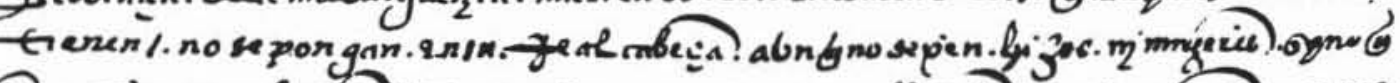

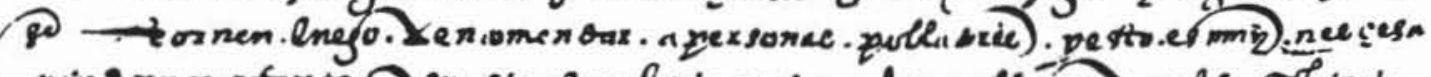

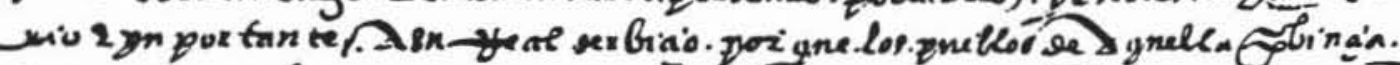

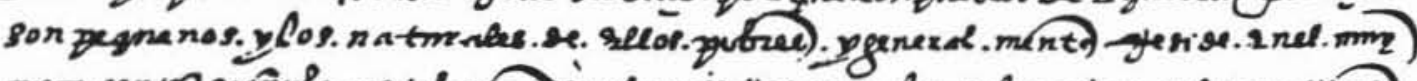

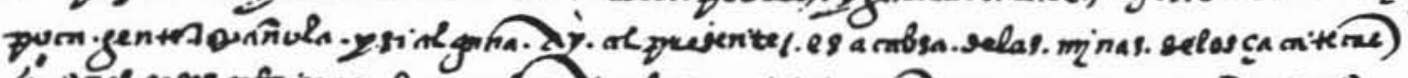

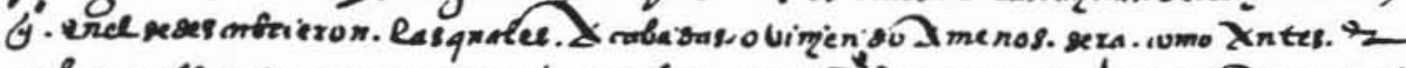

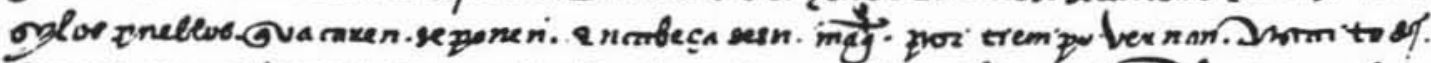

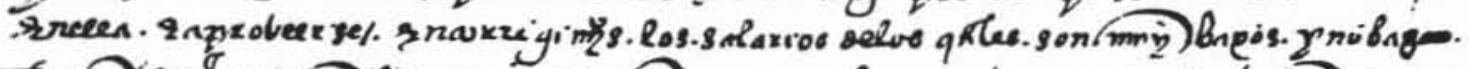

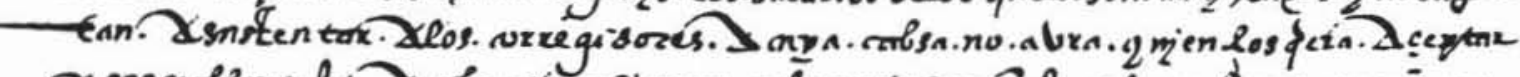

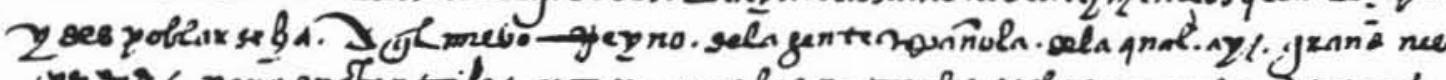

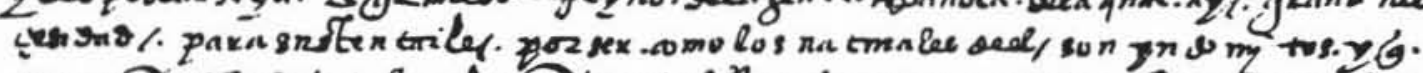

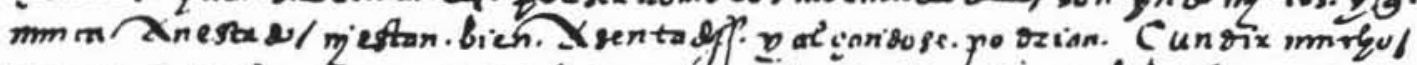

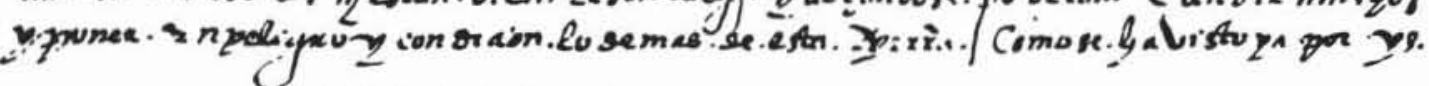

Lámina IV : disençiones en indiano de origen granadino. 


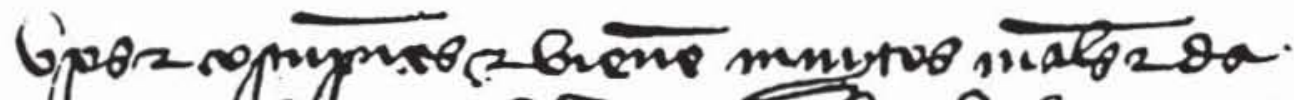

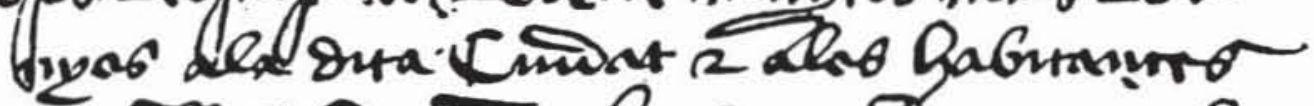

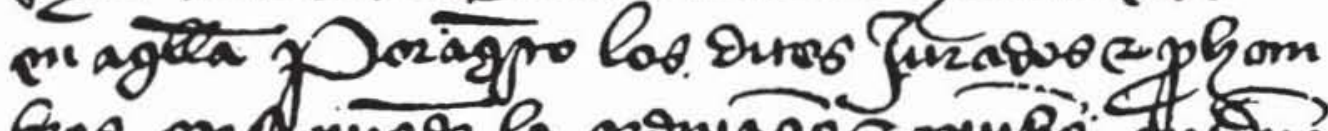

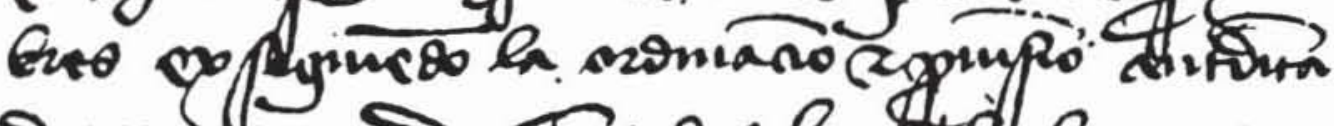

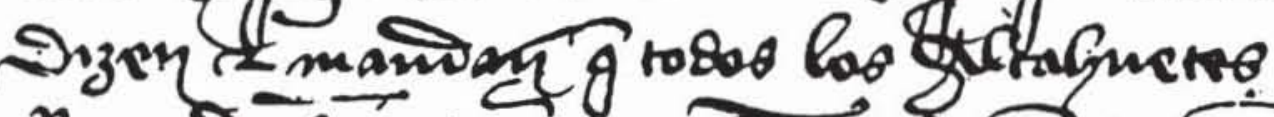

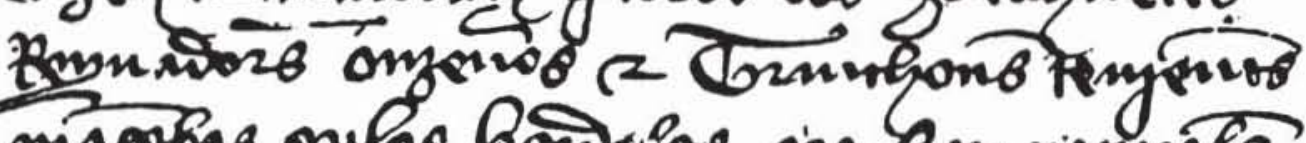

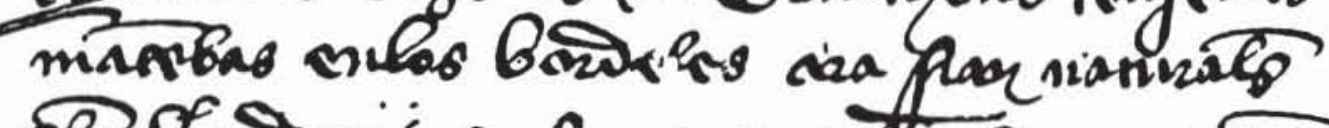

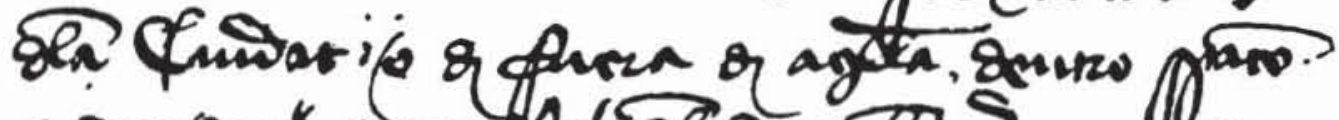

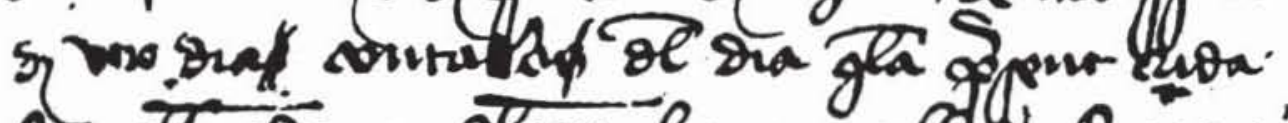

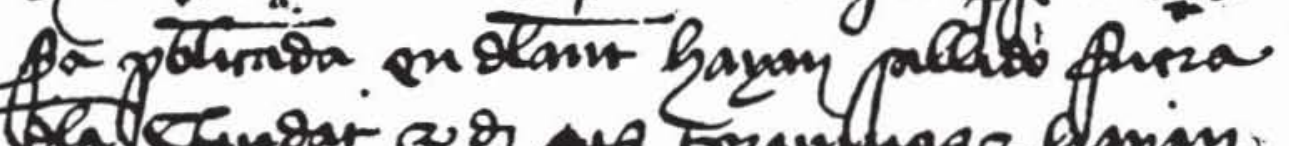

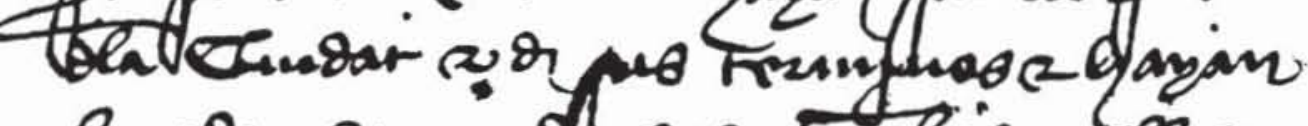



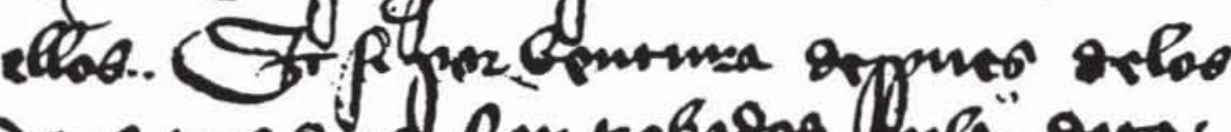

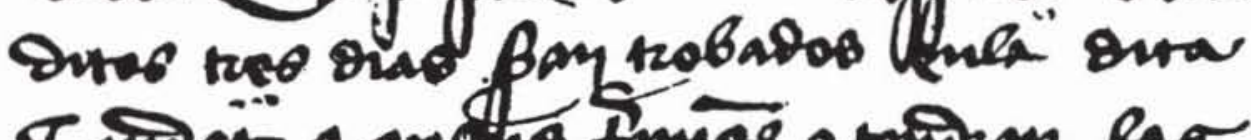

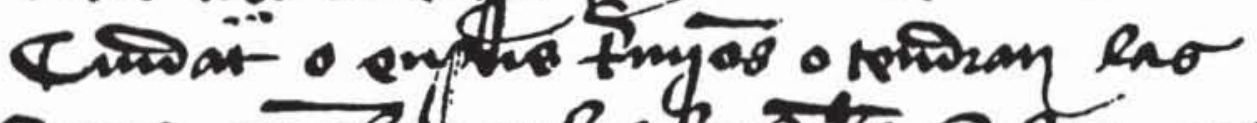

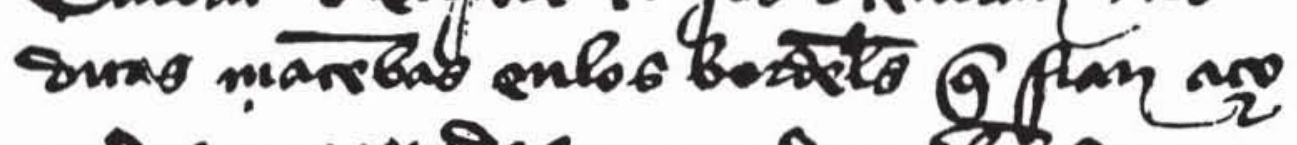

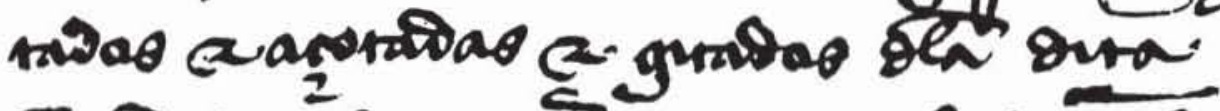

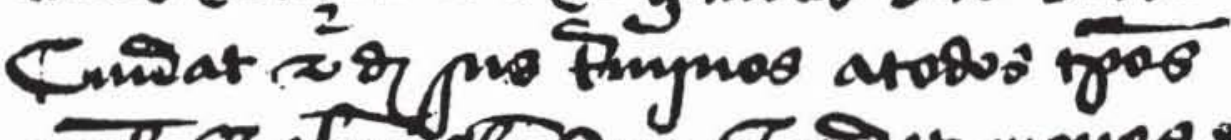

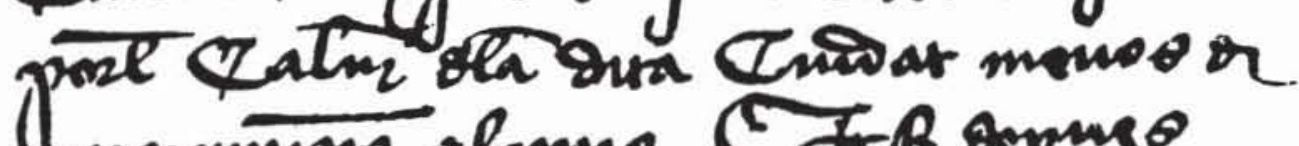

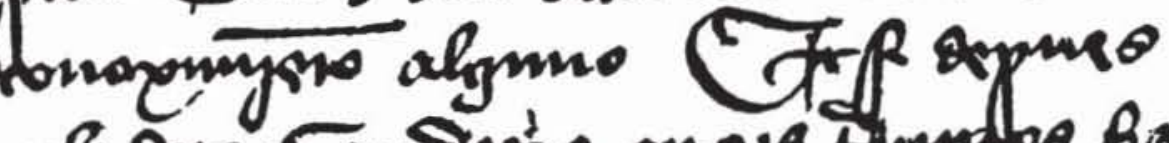

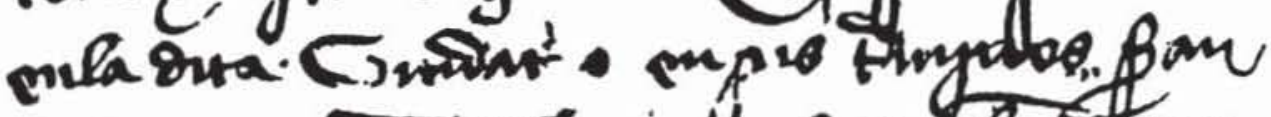

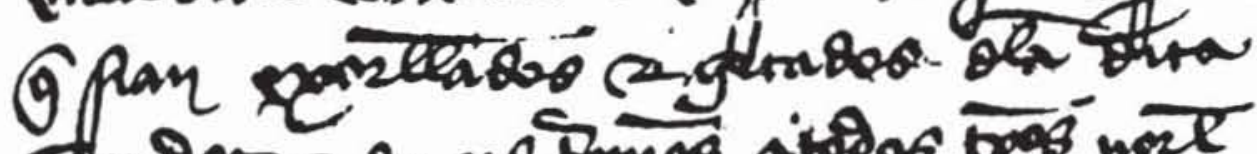

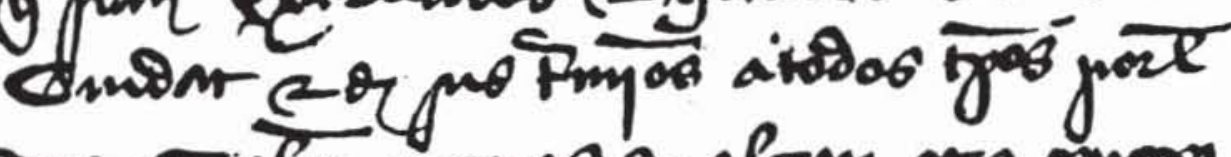
ono Fater menos of afgm otzo ronoc!

Lámina V: Correcciones de $-s$ en documento aragonés. 


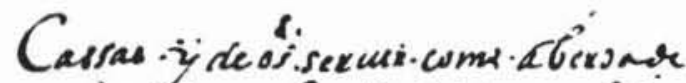
wo. scriver mis ycos dar nail

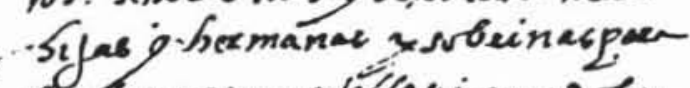
quefus sizuay odistias y quaxsorfue resce. alate gerrac. de io tleune veás

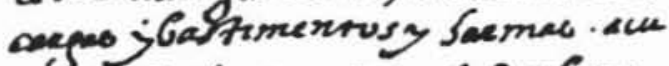

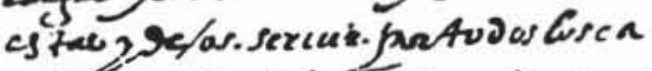

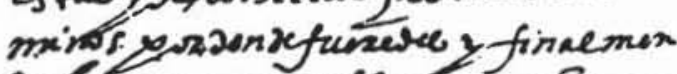

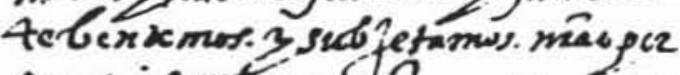

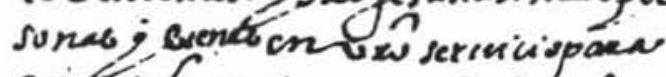

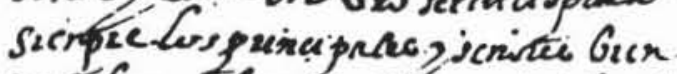

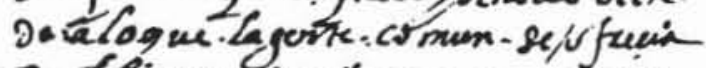

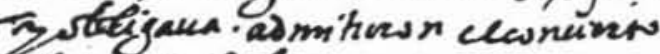
2. Au manostey ma menr le gue nes

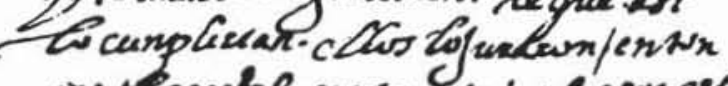

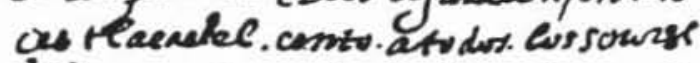
Boue en cscaputalew be auiopressab

Frov al reir comola no auit quees. perar parquel rescić Samia at $2 x$ sictucion. mandadu no bolucsement

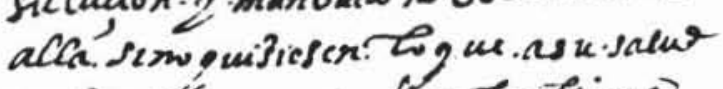
conbemil. $q$ que esto heratovitiono que.crustipareax ausa.

QOust.por.ce rem mme a tlacacice queding. mañiass. apexpibiegents is poneis la in'se ort lo quartuche.

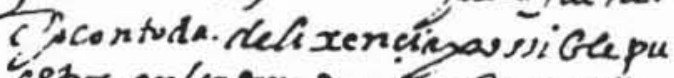

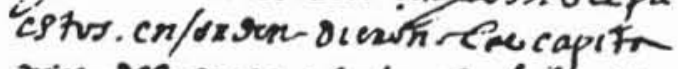
mias regente. a to do tes higise cosice passaver. asificimanof

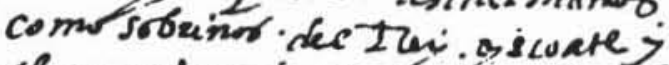
chos mac prenajoake icuivos Susw

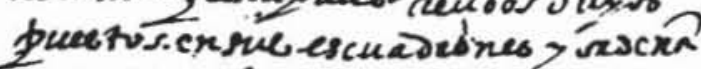
ga.teles hice vnaplatica.atus

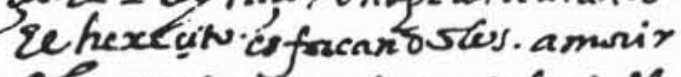

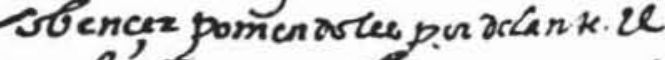
mobre guesicmpe. Tt neaion mori carra-bavia terrov criside mu no 3 pues-aquelshera cepuimex cunba Te-o uppasn maxcon borrza y hace timer $\operatorname{tar} b$ lo a lao remañ cionec hom aquel givenede mo vel

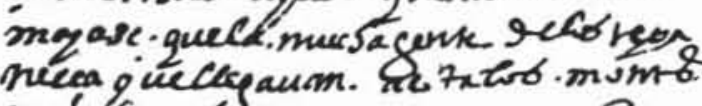
no hicis atross. sinuce amino Gav

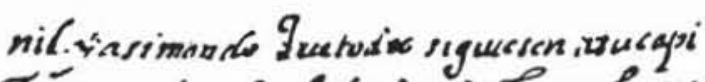

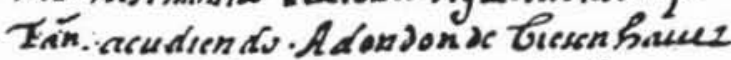
mas.mecssseb-2 quemingum hïchaspic Adelan te sinu fureminesa 2 aunato

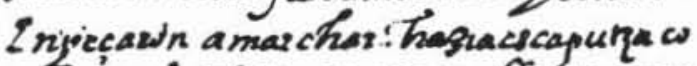

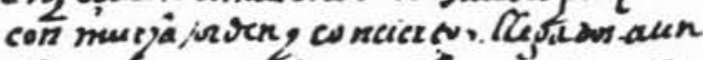
Cupar que se dia joconocinopalititan 2 or. de ascaputzact Tos satiezurn afenourerts

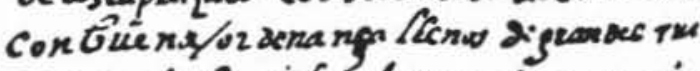

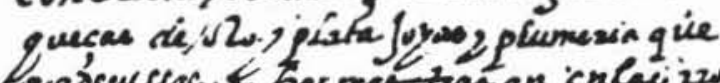

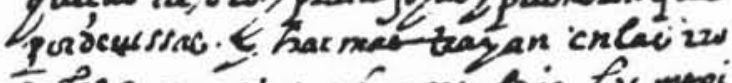
Detas a a cuestac atás cspabio. Fus mexi

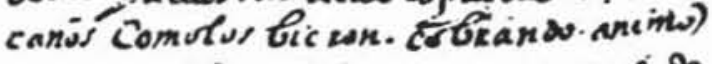

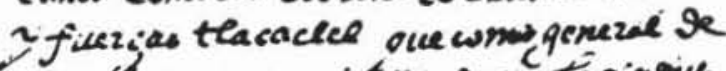

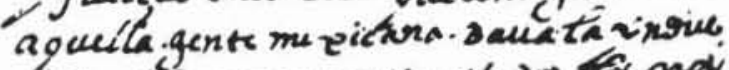
tria. té́a pueza mando atudu tac agy tance y senvie 2 mancetos ace mos tza t tan casto re Tágerris geceptices tus. crun alteluy dalasmal tes a tanbie are

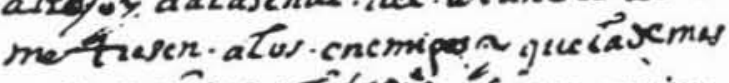

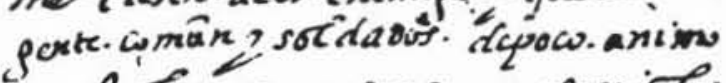

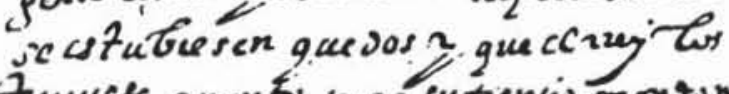
4 unser apunti paxa sutienpis moovin

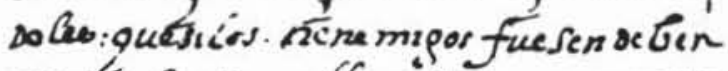
ci dan. sc fuesen. allepariou. pucu apuce cn

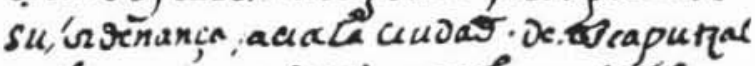

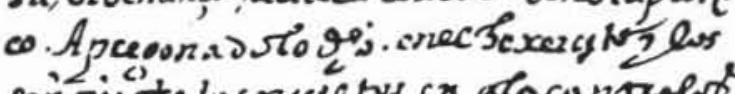

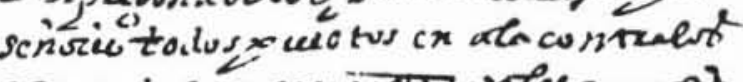

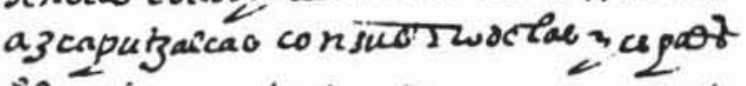
ie merin zwate toco Ungequeno atan bn y us hital cspac dee toura. Aesoniesquac alcaror tus mexicanós todos tis bee he

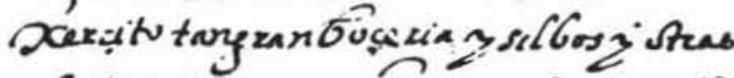
agparazas guepuriewn grantemusent natingente contrarin 3 arkeme tiong ros. senozec to due lisque sotacia in

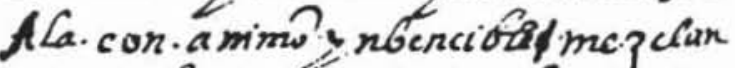

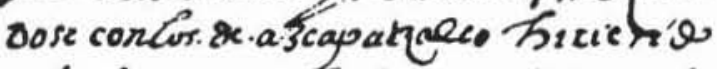
adicstio.3.asimestion.sinfisen.micn ciertu enpecaun.axaclisare mexico mexicu de taesuente. Ciss ac. Gor ot

Zun: que enpeçaus $n$ encrocr. Uorish qiue

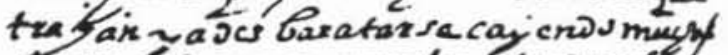

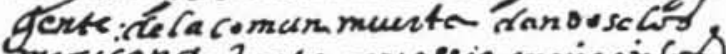
mexicans. Zanta oricssing mariacinfors

Lámina VI : $-s$ anómala enmendada por fray Diego Durán. 


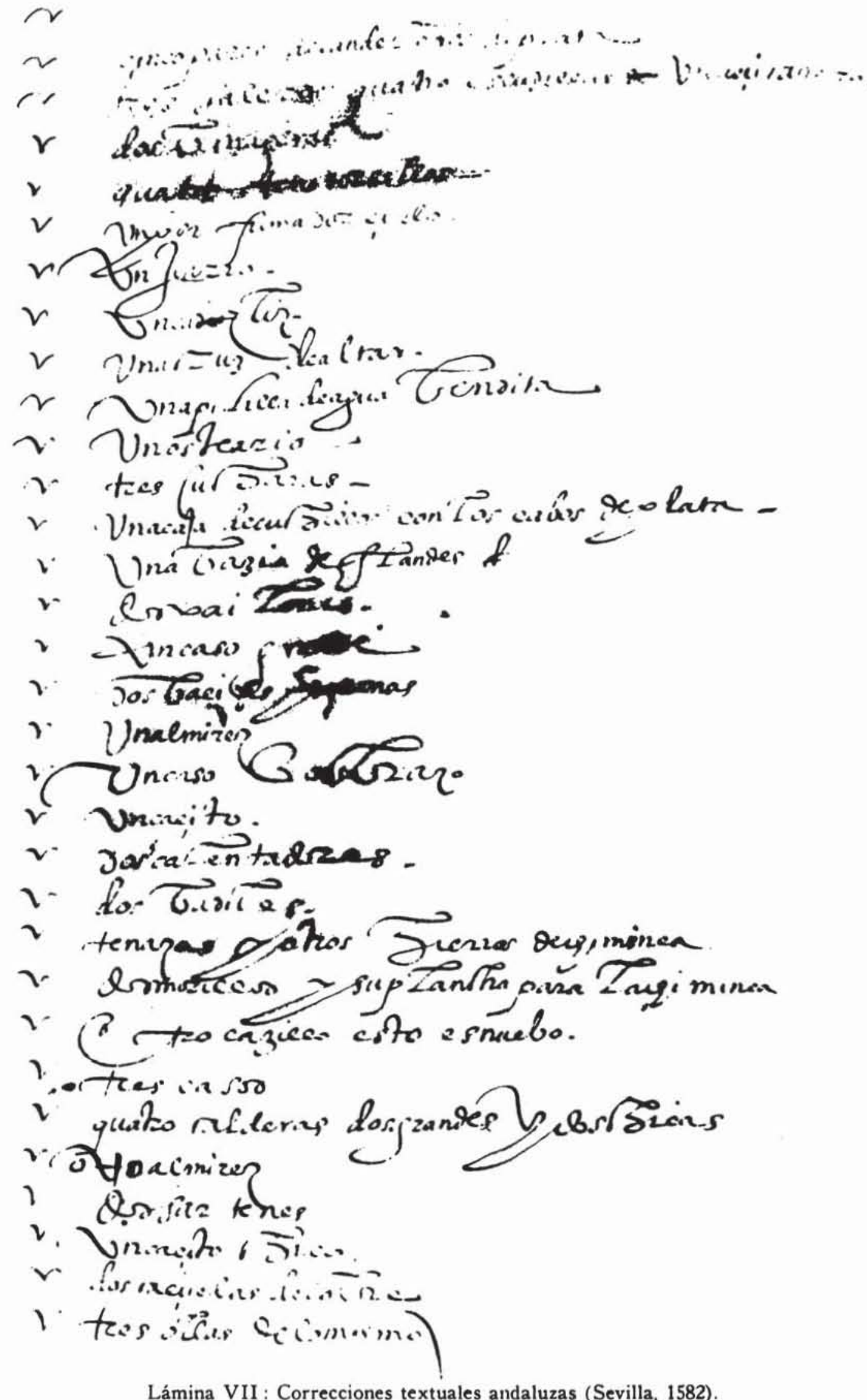

Lámina VII : Correcciones textuales andaluzas (Sevilla, 1582). 